\title{
Mechanical Regulation of Signaling Pathways in Bone
}

\author{
William R. Thompson ${ }^{\mathrm{a},{ }^{*},}$ Clinton T. Rubin ${ }^{\mathrm{b}}$, and Janet Rubin ${ }^{\mathrm{a}}$ \\ William R. Thompson: wthomp@med.unc.edu; Clinton T. Rubin: clinton.rubin@sunysb.edu; Janet Rubin: \\ jrubin@med.unc.edu \\ aDepartment of Medicine, University of North Carolina, Chapel Hill, NC 27599 \\ bDepartment of Biomedical Engineering, The State University of New York (SUNY), Stony Brook, \\ NY 11794
}

\section{Abstract}

A wide range of cell types depend on mechanically induced signals to enable appropriate physiological responses. The skeleton is particularly dependent on mechanical information to guide the resident cell population towards adaptation, maintenance and repair. Research at the organ, tissue, cell and molecular levels has improved our understanding of how the skeleton can recognize the functional environment, and how these challenges are translated into cellular information that can site-specifically alter phenotype. This review first considers those cells within the skeleton that are responsive to mechanical signals, including osteoblasts, osteoclasts, osteocytes and osteoprogenitors. This is discussed in light of a range of experimental approaches that can vary parameters such as strain, fluid shear stress, and pressure. The identity of mechanoreceptor candidates is approached, with consideration of integrins, pericellular tethers, focal adhesions, ion channels, cadherins, connexins, and the plasma membrane including caveolar and non-caveolar lipid rafts and their influence on integral signaling protein interactions. Several mechanically regulated intracellular signaling cascades are detailed including activation of kinases (Akt, MAPK, FAK), $\beta$-catenin, GTPases, and calcium signaling events. While the interaction of bone cells with their mechanical environment is complex, an understanding of mechanical regulation of bone signaling is crucial to understanding bone physiology, the etiology of diseases such as osteoporosis, and to the development of interventions to improve bone strength.

\section{Keywords}

Mechanoreceptor; Skeleton; Integrin; Focal adhesion; $\beta$-catenin; RhoA; Osteoporosis; Mesenchymal stem cells

\section{Introduction}

The skeleton provides a structural framework that facilitates locomotion and activities of daily living. Strategies to avoid skeletal failure are critical to the survival of any vertebrate, not the least of which is bone tissue's intrinsic ability to perceive and adapt its morphology

\footnotetext{
(C) 2012 Elsevier B.V. All rights reserved.

*Corresponding Author: William R. Thompson, DPT, PhD, wthomp@ med.unc.edu, Ph.: (919) 966-6743.

Conflict of Interest: CTR has several patents related to the mechanical stimulation of bone, and is a founder of Marodyne Medical. No other authors have any conflicts of interest.

Publisher's Disclaimer: This is a PDF file of an unedited manuscript that has been accepted for publication. As a service to our customers we are providing this early version of the manuscript. The manuscript will undergo copyediting, typesetting, and review of the resulting proof before it is published in its final citable form. Please note that during the production process errors may be discovered which could affect the content, and all legal disclaimers that apply to the journal pertain.
} 
to accommodate new functional demands (Wolff, 1892). As such, the skeletal response to greater physical challenges results in larger and stronger bones (Karlsson et al., 1993), a response achieved by site-specific adaptations rather than a global skeletal change (Kannus et al., 1994a). Conversely, reduced physical demands, such as those associated with chronic bed rest or the consequences of aging, will accelerate losses in bone quantity and quality, and the ensuing osteopenia can lead to intractable morbidity, increased risk of fracture, and - invariably - a loss of independence (Krasnoff and Painter, 1999).

To address skeletal fragility, most medical strategies have focused on either promoting osteoblast activity (anabolic strategies) or inhibiting bone resorption (antiresorptive strategies), using hormones or chemical compounds to systemically amplify or disrupt specific parts of the remodeling cycle (Lyritis et al., 2010). These strategies fail to take advantage of the intrinsic ability of bone tissue to adapt to external forces from the environment, which relies on the close orchestration of both formation and resorption in those specific sites of the skeleton that are subject to unique loads. Understanding the molecular pathways governing the ability of bone to respond to functional demands should lead to novel therapeutic strategies for musculoskeletal disorders, from optimized exercise regimens to drugs that exploit key signaling molecules involved in mechanosensitivity.

Our principal goal in this review is to highlight new developments in mechanical signaling systems by which bone cells and their precursors are known to respond to their physical environment. We will begin with an introduction to mechanically responsive bone cells and consider their biophysical environment experienced during physiological loading. We then consider how the responsive cell converts environmental signals into biochemical signals in the process of mechanotransduction. We will cover candidate receptors and highlight signaling systems activated by mechanical input. While it is not possible to detail the entire field of mechanotransduction, our goal is to provide some perspective towards the multiplicity, and complexity, of signaling systems that respond to mechanical input.

\section{Mechanically responsive bone cells}

Nearly all cell types, including myocytes (Aikawa et al., 2002), platelets (Goncalves et al., 2005), endothelial cells (Shyy and Chien, 2002), chondrocytes (Millward-Sadler and Salter, 2004), fibroblasts (Tadokoro et al., 2003), and bone cells (Salter et al., 1997), are mechanosensitive (i.e., able to sense and respond to biophysical factors in the environment). While much progress has been made in understanding regulatory events that control the mechanical responses of the inner ear (Puel, 1995), cardiovascular (Dahl et al., 2010), and renal tissues (Weinbaum et al., 2010), the mechanosensing mechanisms and component cellular constituents in bone are still poorly understood. What is known is that multiple bone cell types, and their precursors, work in a complex spatial and temporal concert to control bone modeling and remodeling.

The ability of bone to sense and respond to mechanical forces is orchestrated by at least four cell types: the bone resorbing osteoclast of hematopoietic origin, the mesenchymal-derived bone forming osteoblast, its terminally differentiated state embedded within bone, the osteocyte, and the osteoprogenitor itself, the mesenchymal stem cell (MSC). Except for the osteoclast, which derives from the macrophage lineage of hematopoietic stem cells, these cells represent progressive stages of the MSC that in response to bone formative signals differentiates into a phenotypic osteoblast; the osteoblast, when buried in a mineralized matrix of its own making, then terminally differentiates into an osteocyte. Each of these cell types is independently sensitive to mechanical signals and further, through their interaction with each other and their precursors, can serve as critical regulatory elements in the recruitment, proliferation and differentiation of osteoclasts and osteoblasts. This coordinated 
regulation is evident in studies that show that application of mechanical strain to murine marrow derived stromal cells reduced $1,25(\mathrm{OH})_{2} \mathrm{D}_{3}$-stimulated osteoclast formation by half, significantly reducing mRNA expression of receptor activator of NF kappa B ligand (RANKL) (Rubin et al., 2000). While production of RANKL by osteoblasts has long been posited as the agent that links osteoblast and osteoclast activity, and thus bone remodeling events, recent work indicates that osteocytes, not osteoblasts, are the major source of RANKL in the unloaded skeleton (Xiong et al., 2011). These studies highlight the temporal and spatial coordination between multiple cell types extant in bone, which together regulate adaptive changes in response to alterations in the mechanical environment.

Mechanical control of osteoclast function appears to occur largely through regulation of osteoclast recruitment, which is achieved through osteoprogenitor lineage expression of RANKL (Yasuda et al., 1998). Cells of the osteoprogenitor lineage, in turn, are located in mechanically active environments, and respond to mechanical cues with alteration in proliferation, differentiation and differentiated function. The MSC lineage is sensitive to mechanical stimuli from its stem cell origin and throughout development up to, and including, the terminally differentiated osteocyte. The early MSC, sharing the hematopoietic niche with blood stem cells, responds to the mechanical environment of the marrow by altering output of differentiated cell types (David et al., 2007; Sen et al., 2008). Early osteoprogenitors can respond by increasing rates of clonal proliferation and enhancement of differentiation (Case and Rubin, 2010).

The osteocyte, which is uniquely situated in cortical bone to sense mechanical strain and load generated factors (e.g., fluid flow, streaming and pressure) through a connected network of sister cells (Bonewald, 2011), contributes to the perception of and response to loading and unloading. At the very least, this canalicular network responds to unloading, or a decrease in mechanical signals, with upregulation of the proteins sclerostin and RANKL that control bone remodeling at multiple levels (Tatsumi et al., 2007; Xiong et al., 2011). The long osteocytic processes are able to pass information between cells separated by hard tissue (see canalicular projections from an osteocyte in Fig. 1). It is likely that these cells generate soluble factors that modulate MSC differentiation as well as osteoprogenitor recruitment to areas of bone remodeling, but this has not yet been proven. How osteocyte RANKL is delivered to hematopoietic stem cells to instruct osteoclast differentiation, presumably through canaliculi, and how new osteoclasts are recruited to sites of bone resorption, is unknown,

Lineage allocation of MSCs is influenced by mechanical signals. The output of osteoblasts and adipocytes assumes a reciprocal relationship in many conditions; for instance, during exercise induced increase in marrow osteoblasts, there is a reduction in marrow adipocytes (David et al., 2007; Sen et al., 2008)). Our lab has demonstrated the ability of mechanical strain to inhibit adipogenic differentiation, a process that critically involves $\beta$-catenin (Case et al., 2010). The stability of $\beta$-catenin is regulated by GSK3 $\beta$, which we have recently demonstrated is dependent on mTORC2 phosphorylation of Akt (Case et al., 2011b). Additionally, varying the delivery of mechanical input may enhance the effects of loading on MSCs: incorporating a refractory period into the loading regimen further enhances the anti-adipogenic effects of mechanical stimulation of MSCs (Sen et al., 2011b). The temporality of mechanical signal delivery likely has effects on multiple timescales, as will be discussed.

In summary, all bone cells have the capacity to respond both directly and indirectly to mechanical signals, but bone quality and quantity are ultimately defined by highly regulated cellular interactions, including osteocyte control of anabolic and catabolic turnover, 
signaling between precursor cells within the marrow hematopoietic niche, and coordinated effects between osteoblasts and osteoclasts.

\section{Mechanical environment of bone}

The mechanical environment to which bone cells are exposed is a dynamic milieu of biophysical stimuli that includes strain, stress, shear, pressure, fluid flow, streaming potentials and acceleration. While ultimately it may not be possible to separate specific effects of each of these factors, it is clear that several of these parameters independently have the ability to regulate cellular responses and influence remodeling events within bone. Furthermore, components of these specific factors - such as magnitude, frequency, strain rate - also affect the cellular response. For instance, loading studies demonstrate that certain degrees of loading must be achieved to elicit changes (MacKelvie et al., 2003), but that magnitude is only one of many factors that are important to outcome (Hert et al., 1971; Rubin and Lanyon, 1985). The extent of the response is also influenced by the rate of strain (O'Connor et al., 1982), number of loading cycles (Rubin and Lanyon, 1984b), frequency (Hz; cycles per second) (Rubin and McLeod, 1994; Qin et al., 1998) and the dynamic nature (temporal variation) (Lanyon and Rubin, 1984) of the imposed mechanical signals.

\subsection{Biophysical factors generated during loading}

Any form of activity, whether climbing stairs, jogging, or even standing in the kitchen, results in skeletal load and thus invariably induces deformation of the bone matrix. Because bone is mineralized, loading generates relatively small strains. During strenuous actions, maximal strain measured in a range of locations (e.g., tibia, femur, humerus, ulna) in a variety of vertebrates (e.g., horse, human, goose, sheep) fall within a confined range of $2,000-3,500(1,000=0.1 \%$ change in length from the original length) (Rubin and Lanyon, 1984a). While approximately $0.7 \%$ deformation represents the upper limit of bone strain before irreversible damage accumulates (i.e., yield strain) (Carter et al., 1981), these levels are markedly lower than those that are generated in ligaments (5\% strain), tendon (20\% strain), or cartilage (30\% strain) during loading (Frost, 1983).

During daily functional activities, peak bone loading occurs at relatively low-frequencies (1-3 Hz) (Fritton et al., 2000); and even then, only for a very few cycles per day (Adams et al., 1997). In contrast to the rarity of these high-magnitude mechanical events, the skeleton is continually subject to extremely low-magnitude $(<5 \mu \varepsilon$, or $<0.0005 \%)$, high-frequency events $(10-50 \mathrm{~Hz})$, a product of the constant muscle contractions essential to maintain posture (Huang et al., 1999). The presence of continual, high-frequency, low-magnitude mechanical signals generated during even "quiet" activities, such as standing, decreases in parallel with age-related muscle atrophy (Huang et al., 1999) and thus sarcopenia with deterioration of this mechanical signaling may directly contribute to age-related bone loss. The importance of mechanical loading in achieving and retaining the structural integrity of the skeleton is further illustrated by the rapid bone loss that accompanies skeletal unloading such as occurs with chronic bed rest (LeBlanc et al., 2000), spinal cord injury (Modlesky et al., 2004) or cast immobilization (Kannus et al., 1994b). The most extreme example can be found in astronauts where life in microgravity results in a dramatic loss of bone tissue (Carmeliet et al., 2001), reaching as much as $2 \%$ bone density loss at the hip per month (Lang et al., 2004).

The extensive network of canaliculi within the ultrastructural anatomy of bone contains interstitial fluid surrounding osteocytes, which may serve as a means of amplifying bone tissue strains (see Fig. 1). Furthermore, motion of fluid within this system generates shear forces on bone cells. While the pressure differential of the circulatory system may account for some of the interstitial fluid flow within bone (Dillaman et al., 1991), exogenously 
applied mechanical loading is likely the major driver in bulk fluid flow (Piekarski and Munro, 1977). Dynamic loading generates an oscillatory fluid flow, which may affect cells differently than laminar shear (You et al., 2001a; Case et al., 2011a), as described in several theoretical models (Weinbaum et al., 1994; Cowin et al., 1995). Oscillatory fluid movement appears to be a more potent signal than constant flow, supporting the finding that dynamic, not static, mechanical signals are required for bone adaptation.

Bone cells are also exposed to and respond to pressure, which varies at lacunocanalicular and intramedullary sites during loading. Physiological levels of (static) hydrostatic pressure $(138 \mathrm{kPa})$ were sufficient to decrease osteoclast formation in bone marrow cultures (Rubin et al., 1997) and to enhance production of $\mathrm{PGE}_{2}$ and decrease collagen synthesis for osteoblastic cells (303 kPa) (Ozawa et al., 1990). MC3T3-E1 osteoblastic cells subjected to either cyclic hydraulic pressure $(0-68 \mathrm{kPa}$ at $0.5 \mathrm{~Hz})$ or fluid shear stress $\left(12 \mathrm{dynes} / \mathrm{cm}^{2}\right)$ demonstrated similar increase in ATP release and COX-2 expression (Gardinier et al., 2009). Interestingly, the magnitude of pressure experienced by osteocytes is postulated to be 1,000 -fold greater than that of osteoblasts under an equal physiological loading regimen, due to amplification by the constrained boundary conditions of the lacunocanalicular networks (Gardinier et al., 2010).

\subsection{Enhancing mechanical response: frequency of signal and dose}

The various methods to load bone and bone cells commonly apply those peak challenges experienced by the skeleton that have been considered to contribute most towards an anabolic response. However, bone is put at risk of fracture when loads become exceedingly high. Similar to other sensory systems such as vision, hearing or touch, bone also has the capability of sensing and responding to "other than peak" signals within a broad range spectrum (Ozcivici et al., 2010). As such, it is important to note that bone does not necessarily require an extreme mechanical signal to elicit an adaptive response. Thus, when considering that the functional milieu of bone ranges from very few, low-frequency, highmagnitude events to the omnipresent, high frequency, low-magnitude events (Fritton et al., 2000) it is interesting to point out that the adaptation of bone follows this path, with an anabolic response that can be elicited by very few high-magnitude strain events (Rubin and Lanyon, 1985), or by tens of thousands of low-magnitude strain events (Qin et al., 1998).

High-frequency, low-magnitude mechanical stimulation (LMMS), commonly introduced using low intensity vibration (LIV), is a non-invasive means of applying a very high number of low-magnitude strain events to the skeleton. An example of the adaptive response to one year of low intensity vibration $(0.3 \mathrm{~g}$ magnitude, $30 \mathrm{~Hz} \times 20 \mathrm{~min} /$ day $)$ is shown in Figure 2, where CT of the distal femur of sheep revealed increased trabecular bone density (Rubin et al., 2001). That these extremely low magnitude signals, three orders of magnitude below the peak strains generated by strenuous activity, resulted in enhanced bone strength, emphasizes that signals need not be large to be influential. Computational models demonstrated that the buttressing of trabeculae, through enhanced connectivity and plate-like struts, served as an effective strategy to reinforce the bone structure in those regions where the LMMS signal was greatest (Judex et al., 2004).

The interdependence of loading parameters is further complicated by complex dynamics of timing, where very short refractory periods between cycles of loading enhance bone formation in vivo (Srinivasan et al., 2007), and separating loading into multiple short bouts enhances bone structure (Robling et al., 2002). In vitro, longer rest periods between load applications induce cellular adaptations with an enhanced response: a rest period between bouts of loading of at least 1 hour facilitated decreased adipogenic allocation of MSC resulting in an increased osteogenic response (Sen et al., 2011b). 
While a multitude of studies demonstrate the ability of bone tissue to respond to a diverse range and type of mechanical signals, these physical stimuli are not mutually exclusive. Loading the skeleton generates all of these forces concurrently; thereby induction of fluid shear stress cannot be separated from the effects of transient pressure waves, cell strain or nuclear accelerations. Indeed, surrogates for mechanical signals used in the clinic to stimulate bone repair of fractures and non-unions, such as pulsed-electromagnetic fields (Griffin et al., 2011) and ultrasound (Heckman et al., 1994) are based on providing physical signals to the bone cell population without the need to actually apply a load. The use of animal models or clinical studies to provide insight into how the target cell perceives and responds to the mechanical signal is limited. To improve our understanding of the nature of mechanotransduction, scientists study bone cells and their progenitors using in vitro techniques, affording greater control of the cell's response to the introduction of mechanical signals.

\subsection{Experimental loading models}

Investigating the response of bone to loading at the in vivo level presents investigators with a host of challenges, not the least is how to introduce physiologically relevant loads, and then to isolate and reduce responses to any specific biophysical component of the load. Methods for applying mechanical load include dynamic compression of the functionally isolated turkey ulna (Rubin and Lanyon, 1984b), bending of the rat and mouse ulna (Mosley et al., 1997) and tibia (Gross et al., 2002), four-point bending applied to rat tibia (Lee et al., 2003), and the non-invasive application of high frequency, low magnitude signals through the use of vibrating platforms (Xie et al., 2006). Specific mechanical parameters of any loading regimen can be correlated to specific changes in bone morphology (Rubin and Lanyon, 1985; Rubin et al., 1996; Srinivasan et al., 2002) as well as alterations in gene and protein expression (Judex et al., 2004; Moustafa et al., 2011).

In addition to these in vivo models designed to understand how bone loading drives bone formation, hind-limb unloading of animals has been a frequently used method to simulate disuse (Globus et al., 1986). Unloaded models have shown the rapid loss of bone in the affected limb, as well as adipogenesis within the bone marrow stem cell population, indicating reduced MSCs and greater marrow adiposity (Meyers et al., 2005). In an attempt to simulate reduced gravity environments more relevant to clinical conditions, a partial weight suspension model has recently been developed to allow investigation of adaptation to reduced skeletal loading (Wagner et al., 2010). This model has advantages over hind limb unloading conditions by creating a less stressful physical environment for the animal while generating similar losses in bone mineral and bone structure.

To better understand molecular mechanisms involved in mechanical signaling, in vitro systems to mechanically load cells in vitro have been developed. In contrast to the very small strains necessary to induce physiological changes in vivo, mechanical challenges applied to bone cells in vitro are typically delivered at much larger strains, on the level of $0.5-10 \%$, and applied at relatively low frequencies $(0.1-1.0 \mathrm{~Hz})$ (Murray and Rushton, 1990; You et al., 2000). This reflects a paradox whereby bone tissues are subject to, and require, only very small strains to induce adaptive responses, while at the in vitro level strained bone cells require a much larger deformation to obtain measurable cellular responses. Some of this may be explained by synergistic combinations of multiple signaling pathways, or by non-physiological conditions during cell culture, such as the two dimensional nature of most culture conditions, or by the limited time frame of an experiment. One possible explanation is that biophysical factors experienced by cells within bone are greater than those measured from the mineralized matrix tissue itself, by virtue of their connections and constraints of the bone architecture. For instance, Han and colleagues proposed that the cellular processes of osteocytes are stiffer than the cell body, facilitating a 
normal physiological strain of the bone tissue to be amplified to upwards of 5,000 $\mu \varepsilon$ (Han et al., 2004). Indeed, the application of local deformation to osteocyte cellular processes resulted in a greater cellular response compared to a similar deformation at the cell body, suggesting that the cellular morphology contributes to a differential mechanosensory response between the processes and body of the cell (Adachi et al., 2009). It should be noted, however, that high frequency, low magnitude signals are quite effective in vitro: when applied twice daily, a high frequency regimen that imposed less than $5 \mu \varepsilon$ was able to restrain adipogenesis of bone marrow MSC (Sen et al., 2011b).

Another means of amplifying the strain signal in vivo has been proposed following examination of bone structure using electron microscopy images, which defined the spatial parameters of the osteocyte lacunocanalicular system (LCS). These studies revealed "transverse tethering elements" spanning the pericellular space of the osteocyte canaliculi (You et al., 2004). Bioengineers have proposed that pressure-driven fluid movement in the LCS induced a drag on these tethers, thereby producing strain on the cell membrane at least one order of magnitude larger than bone tissue deformations (Han et al., 2004; You et al., 2004).

Finally, the constrained fluid flow within the canaliculi may serve to increase fluid velocity and pressure, thus amplifying the signal (Cowin and Weinbaum, 1998). Functional load bearing also causes pressure to build up, and then release, within the intramedullary canal, generating fluid movement from the endosteal to the periosteal surface, and simultaneously mechanically stimulating the bone marrow stem cell environment (Qin and Lam, 2009). Laminar and oscillatory loading has been used extensively to stimulate cells in vitro by various engineered systems (Williams et al., 1994; Bacabac et al., 2002; Case et al., 2011a).

\section{Candidate mechanoreceptors}

Even with the functional environment of the skeleton largely characterized, and a first order approximation of the types of mechanical signals that drive the adaptive response within reach, it still remains unclear how cells perceive these dynamic physical signals. One of the most provocative questions in cell response to a mechanical signal is the nature of the mechanosensor. A mechanosensor may be defined as any molecule, protein complex, or biological structure capable of detecting alterations in force. Mechanosensors are found in nearly every cell type and are responsible for essential functions such as touch sensitivity via pacinian and meisner corpuscles (Vega et al., 2009), hearing induced by stereocilia deformation in the cochlea (Ingber, 2006), and neurosensory feedback in virtually every organ system (Chalfie, 2009).

The ability of cells to sense the mechanical signals from the environment requires that mechanoreceptors either directly contact with the extracellular space, or that a mechanoreceptor can distinguish changes in a physical intermediary such as pressure or fluid shear on the plasma membrane. Candidate mechanoreceptors span the gamut of specific receptors for force that respond with conformational changes in proteins, candidate structures such as primary cilium, or harder to define responders that regulate protein interactions such as mechanically induced alterations in components of plasma lipid, or interactions with the extracellular matrix (ECM) or the cell cytoskeleton.

Mechanotransducer candidates are presented graphically in Figure 3. While many models attempt to demonstrate the involvement of a single mechanosensory element to account for specific cellular responses, it is likely that many of these mechanoreceptors contribute to and interact in ultimately defining the response of the cell to its mechanical environment. 


\subsection{Outside-in mechanosensors: tethers and integrins}

Anchoring of the cell to the ECM provides a sense of location and an ability to perceive biophysical changes in the environment. These anchorage sites are so essential to proper cellular signaling/communication that defective attachment results in death of normal cells. Deformation of the cell membrane, whether through fluid flow, pressure variations, vibration, dynamic strain, etc., is transmitted to the cytoskeleton through cell-matrix adhesion proteins (Katsumi et al., 2004). Attachment to the ECM is essential for mechanotransduction and therefore the mechanical integrity of the cell is dependent upon the components of the protein complexes responsible for these attachments, including the membrane constituents.

The presence of cellular scaffolds (both intra- and extra-cellular) provides a framework through which various signaling components, structural proteins and membrane domains are spatially positioned to integrate and transmit mechanosensory signals to the effector machinery of the cell (Farach-Carson and Carson, 2007; Shao et al., 2009). Whether each component of the scaffolded complex is a mechanoreceptor per se or the sum total of these elements is necessary for a cellular response has yet to be determined (see Fig. 3A).

Theoretical modeling (You et al., 2001b) and imaging data (You et al., 2004; Thompson et al., 2011b) postulate that "tethering elements" connecting the cell membrane to the ECM of bone may provide a structural linkage through which fluid shear stress can induce mechanosensory responses in osteocytes and other cells. Tethering elements are "outside-in" connections of the cell to its environment, and are postulated to include integrins, and ECM proteins.

Integrins are heterodimeric protein complexes that couple the cell to the external environment by spanning the plasma membrane and forming attachments with the ECM. The binding of extracellular ligands to integrins may initiate intracellular signaling events (outside-in signaling), while modification of intracellular domains also regulates the binding affinity of extracellular attachments (inside-out signaling). The functional integrin dimer is composed of an $a$ and $\beta$ subunit, both of which possess small cytoplasmic domains. Activation of the dimer complex causes a conformational change in the $\beta$ subunit. The spatial distribution of integrins across the cell membrane and the presence of structural and regulatory motifs make these dimers well-suited candidates for mechanotransduction. Experiments where cell integrins are "tugged" via their connections to ECM coated magnetic beads show that molecules are activated that contribute to remodeling of the cytoskeleton - for instance, integrin manipulation activates RhoA, which induces formation of new focal adhesions (Guilluy et al., 2011). Similarly, activating integrins through the ECM enhances myosin II-generated cytoskeletal force, causing activation of focal adhesion kinase and altering motility (Friedland et al., 2009). As such, integrins serve a mechanosensory role in a variety of cells including platelets (Goncalves et al., 2005), endothelial cells (Shyy and Chien, 2002), fibroblasts (Tadokoro et al., 2003), myocytes (Aikawa et al., 2002), chondrocytes (Millward-Sadler and Salter, 2004), and bone cells (Salter et al., 1997).

$\beta 1$ integrin plays important roles in both osteoblasts and osteocytes. Expression of an osteoblast-specific dominant negative form of $\beta 1$ integrin resulted in reduced bone mass with increased cortical porosity in the long bones of mice (Zimmerman et al., 2000). Osteoblasts exposed to fluid flow shear stress upregulated $\beta 1$ integrin expression (Kapur et al., 2003) and activated $\alpha v \beta 3$, which co-localized with src (Weyts et al., 2002). Additionally, mechanical stimulation in mandibular osteoblasts activated a $5 \beta 3$ and subsequently the PI3K/Akt pathway (Watabe et al., 2011). 
Integrins can be assembled with additional adhesion-associated linker proteins with both structural and biochemical function into focal adhesions, which participate in mediating mechanotransduction events. These associated proteins include talin, vinculin (Schwartz, 2010), p130Cas (Sawada et al., 2006) and focal adhesion kinase (FAK). Talin and paxillin bind to the focal adhesion targeting sequence of FAK (Schaller, 1996) and talin associates with the cytoplasmic tail of $\beta$ integrins (Horwitz et al., 1986). It has been proposed that force may initiate changes in conformation of talin thereby altering binding sites for signaling or adapter proteins (del Rio et al., 2009). Paxillin, on the cytoplasmic side of the focal adhesion, may also be a signal initiation site as it is a substrate for FAK and src kinase (Subauste et al., 2004). Another focal adhesion adapter, p130Cas, enhances association of src family kinases following extreme cell stretching (100\%) (Sawada et al., 2006). Cas activation recruits $\mathrm{SH} 2$ domain adapter and signaling proteins, recruits guanine exchange factors (GEFs) and can activate Rap1, which can reinforce integrin activation (Reedquist et al., 2000). The FAK tyrosine kinase is concentrated near focal adhesions (Schlaepfer et al., 1999) and its activation induces integrin clustering (Schaller, 1996). These focal adhesion adapter proteins warrant further investigation in modulating outside-in signaling in association with integrins.

Mathematical models that incorporate data from electron microscopy studies of the LCS, have posited the importance of integrins in fluid flow-regulated membrane deformation in osteocyte canaliculi, with the mechanical signal amplified by the constrained morphology of the cellular process within the tunnel itself (Wang et al., 2008). Additional studies have demonstrated the spatial location of integrins in the osteocyte LCS (McNamara et al., 2009) and their ability to regulate fluid shear stress-mediated gene expression (Litzenberger et al., 2010). In addition to the concept that integrin attachments facilitate mechanical effects, electron microscopy studies demonstrate the presence of "transverse tethering elements" that span the pericellular space of the osteocyte LCS, connecting the mineralized ECM to the membrane of the elongated, dendritic-like processes (You et al., 2004). Based on the fixation methods used, and the size of the molecules spanning the pericellular space, these tethering elements were likely to be proteoglycan in nature, and possibly be involved in sensing fluid flow (You et al., 2001b). A recent study has demonstrated that the heparan sulfate proteoglycan perlecan is present along the osteocyte body and processes in vitro and in mouse cortical bone in vivo. Interestingly, the number of transverse tethering elements was significantly reduced in mice that were deficient in perlecan (Thompson et al., 2011b). This raises the possibility that perlecan spans the pericellular space of the osteocyte canaliculi creating a tether from the cell to the hard tissue. Perlecan also regulates the size of the pericellular space of the osteocyte canaliculi, as the canalicular space was significantly reduced in perlecan-deficient mice (Thompson et al., 2011b). The presence of numerous regulatory motifs in the core protein of perlecan make it an ideal molecule to interact with various membrane-bound receptors that may mediate load-induced fluid shear stress mechanoregulation of osteocytes.

\subsection{Cell Structure: Cytoskeleton and Focal Adhesions}

The structural framework comprised of actin, intermediate filaments, and microtubules produces an internal skeleton by which the cell mediates functions such as cellular and molecular transport, cell division, and cellular structure to name a few. The cytoskeleton provides an inherent means of perceiving and responding to mechanical signals. Fluid shear stress across osteoblasts induces reorganization of actin filaments into contractile stress fibers (Pavalko et al., 1998) while disruption of the actin cytoskeleton reduces the response of bone cells to fluid shear stress (Malone et al., 2007b; Myers et al., 2007). Additionally, enhancement of actin polymerization increases osteogenic differentiation (Arnsdorf et al., 2009). 
Focal adhesions are macromolecular protein complexes that create a connection between the cytoskeleton and the ECM, and mediate regulatory effects of adhesion on cell behavior (Chen et al., 2003). These adhesion sites containing integrins (see above), and the many associated regulatory proteins are excellent candidates for a macromolecular mechanotransducer complex. Focal adhesions through their connections to the F-actin cytoskeleton not only transmit force throughout the cell (e.g., beyond the integrin), but also stimulate a plethora of signaling pathways.

The role that the cytoskeleton plays in transmitting biophysical input has been highlighted for both high mechanical strain and low intensity vibration. The efficacy of both these mechanical inputs to inhibit adipogenesis, and promote osteogenesis of MSCs via $\beta$-catenin activation, was substantially enhanced by adding a rest period to the mechanical regimen (Sen et al., 2011b). To elucidate the nature of this enhancement, we were able to demonstrate that cells respond to mechanical challenge by assembling focal adhesions, which provide a cytoskeletal based platform for signal enhancement via an $\mathrm{Akt} \rightarrow \mathrm{GSK} 3 \beta \rightarrow \beta$-catenin cascade (Sen et al., 2011a) (see cytoskeletal changes after mechanical strain in Fig. 4). Thus, the initial mechanical challenge induces cytoskeletal adaptation in terms of assembly of new focal adhesions/mechanotransducer complexes, that, when exposed to repeated mechanical challenge, generate an increased signal volume by virtue of increased signaling platforms. Focal adhesions further contribute to lineage allocation via their anchoring of cytoskeletal structure, such that the stiffness of the MSC contributes to allocation of lineage (McBeath et al., 2004).

\subsection{Plasma membrane structure}

Once thought of as a simple barrier separating the intra- and extracellular space, the presence of various types of lipids, anchoring and transmembrane proteins, lipid rafts and caveolae are now known to make up a dynamically regulated docking and signaling facilitation system within the plasma membrane. Lipid rafts are highly organized and dynamic assemblies of glycosphingolipids and cholesterol arranged in microdomains with the capacity to coordinate the association of signaling molecules including GTP-binding proteins, kinases, and integrins. The accumulation of many regulatory molecules in one location gives lipid rafts the ability to generate a "critical mass" of signaling effectors whereby crosstalk and directionality of signals can occur efficiently (Lajoie et al., 2009). Indeed, cholesterol depletion of lipid raft microdomains prevents activation of the small GTPase H-Ras required for the anti-osteoclastic effects of mechanical strain (Rubin et al., 2006). As well, lipid rafts are essential for hydrostatic pressure and fluid shear stressinduced activation of ERK1/2 and of c-fos expression in osteoblasts (Ferraro et al., 2004).

Lipid rafts can be categorized as caveolar or non-caveolar. The presence of caveolin proteins produces the characteristic caveolar invaginations, and through binding sites, allows close associations of proteins into signaling complexes (Anderson, 1998). One possible explanation for the regulation of caveolae-induced intracellular signaling is that ECMassociated molecules are clustered with signaling effectors. Indeed, caveolae are important for $\beta 1$ integrin-mediated mechanical activation of the Src-like kinase Csk (Radel et al., 2007). Caveolin-1 regulates the mechanical properties of bone in vivo as well: caveolin-1 knockout mice display increased bone formation rate at trabecular and cortical sites (Rubin et al., 2007). This appears to involve the ability of caveolin-1 to chronically restrict osteoprogenitor entry (Rubin et al., 2007), perhaps through limiting the availability of $\beta$ catenin (Case et al., 2008).

Mechanical stimuli may have additional effects on the plasma membrane independent of lipid rafts. There is evidence to demonstrate that shear or strain can induce conformational changes in intracellular proteins, thus interfering with protein-protein binding or altering 
protein structure. Exposure of various regulatory sites occurs with lengthening of fibronectin in response to tension, revealing the potential for binding of regulatory molecules (Smith et al., 2007). Additionally, the conformational structure of the parathyroid hormone receptor was altered by fluid shear stress in osteoblastic cells (Zhang et al., 2009).

\subsection{Cadherins and other cell - cell connections}

Cadherins are a family of integral membrane glycoproteins composed of a long extracellular domain, a single-pass transmembrane domain, and a small, intracellular c-terminal tail (see Fig. 3B). The intracellular domain anchors the cadherin to the cytoskeleton by associating with multiprotein complexes that include vinculin, $\alpha$ - and $\beta$-catenin (Nelson and Nusse, 2004). These transmembrane anchoring systems are important in numerous processes including differentiation, cell polarity, immune response, cell division and apoptosis (Levenberg et al., 1999; Makrigiannakis et al., 1999; Graziano et al., 2003). In osteoblasts, $\beta$-catenin associates with cadherins on the inner leaflet of the plasma membrane. Fluid shear stress decreases the amount of $\beta$-catenin bound to $\mathrm{N}$-cadherin thus increasing the cytoplasmic pool of $\beta$-catenin (Norvell et al., 2004). The increase in unbound $\beta$-catenin coupled with activation of GSK3 $\beta$ and Akt that occurs after fluid shear stress has been proposed as a potential upstream regulator of $\beta$-catenin nuclear translocation. Thus, cadherins may serve as launching platforms for $\beta$-catenin in response to mechanical stimulation (Bidwell and Pavalko, 2010).

The cytoskeleton regulates cell - cell connections, suggesting another source whereby cells can sense the mechanical environment. Ephrin ligands and their cognate ephrin receptors are an example of this (see Fig. 3B). Ephrins contribute to osteoblast function, and appear to be necessary for differentiation and possibly communication during remodeling (Martin et al., 2010). The restriction of ephrin clustering within the plasma membrane leads to altered signaling, suggesting that the distribution of ephrin receptors modulates the response to incoming signals (Salaita et al., 2010). As such, the noisy environment of signals in which any cell is continuously bathed can be regulated, even interpreted, via mechanical tuning through physical connections, cytoskeleton and substrate.

\subsection{Primary cilia}

A classic example of a mechanosensory organ, the ciliated structure of the cochlea, is responsible for transduction of auditory and vestibular stimuli. Auditory vibrations deflect the tympanic membrane and travel through the cochlea by transfer through very small muscles and endolymph to perturb the basilar membrane. Basilar force generation impacts stereocilia on the apical surface, where the tip of each cilium is linked via myosin and actin filaments. As the cilium bends, increased tension on the membrane results in opening of mechanosensitive ion channels, generating an influx of intracellular $\mathrm{Ca}^{2+}$, causing membrane depolarization and activation of auditory nerve fibers (Ingber, 2006) (see Fig. $3 \mathrm{C})$.

Long ignored by histopathologists, it is now known that nearly every human cell type possesses non-motile, microtubule-based primary cilia (Olsen, 2005), and they are present in bone cells (Federman and Nichols, 1974). These centriole-derived structures are central to kidney morphology where they initiate extracellular calcium-dependent intracellular calcium release in response to bending deformations, with calcium trafficking through channels including TRPV4, inducing transient voltage changes (Praetorius and Spring, 2003; Gradilone et al., 2007). In fact, the absence of kidney primary cilium is responsible for one of the most common genetic conditions, polycystic kidney disease (Praetorius and Spring, 2003). There have been hundreds of mutations described in autosomal dominant primary ciliary dyskinesia (PCD), notably in the protein polycystin-1 (PC1), a membrane-associated 
protein that interacts with polycystin-2 (PC2) to form a mechanically sensitive calcium channel. PC1 can also undergo proteolytic cleavage resulting in nuclear translocation of its cytoplasmic tail, where it interacts with STAT6 and p100 to stimulate STAT6 dependent gene expression (see Fig. 3C) (Low et al., 2006).

The concept that primary cilia might serve as flow or strain sensors in bone cells has been gaining momentum; in osteocytes and osteoblasts, fluid flow-induced PGE2 signaling, independent of intracellular $\mathrm{Ca}^{2+}$ influx, appears to be cilia dependent (Malone et al., 2007a). As well, MSCs exposed to conditioned media from mechanically stimulated osteocytic cells showed induction of osteogenic genes, an effect that was abrogated when primary cilia formation was inhibited in the osteocyte (Hoey et al., 2011). Primary cilia have recently been recognized to modulate Wnt signaling, interestingly causing $\beta$-catenin degradation via non-canonical means: the loss of ciliary function is thus associated with elevated canonical Wnt signaling (see Fig. 3C) (Berbari et al., 2009). In sum, the contribution of primary cilium to multiple aspects of cell behavior, including differentiation, structure, function and cell response to its macro and microenvironment has become an area of intense investigation throughout all of biology.

\subsection{Ion channels and Connexins}

Ion flow through non-ciliary associated ion channels contributes to the function of sensory organs, such as those regulated by movement of mechanosensory bristles (Sukharev and Corey, 2004) or by tension waves (Morris, 1990). Connexins are membrane spanning protein hexamer complexes (each subunit of the complex is called a connexon) that form pores within the plasma membrane of cells. Alignment of connexons with their counterpart on an adjacent cell creates functional connections called gap junctions (see Fig. 3D). The gap junction pore allows for intracellular communication isolated from the extracellular environment, and can pass small molecules $(<1 \mathrm{kDA})$ including calcium, inositol phosphates, ATP, and cAMP (Genetos et al., 2007; Song et al., 2011). Independent of cell-cell gap junctions, connexin hemichannels serve as a portal through which prostaglandins are released from the osteocyte in response to fluid shear stress. Interestingly, autocrine/ paracrine activation of cAMP/PKA and PI3K/Akt pathways leads to inactivation of GSK3 $\beta$ leading to increased nuclear translocation of $\beta$-catenin, which regulates connexin 43 (Cx43) transcription (Xia et al., 2010). Evidence from Cx43 knockout mice demonstrates delayed expression of genes coding for bone matrix proteins including osteocalcin and osteopontin (Chaible et al., 2011). Additionally, gap junction phosphorylation and function are mechanically regulated and are responsible for expression of bone matrix proteins in osteoblasts (Alford et al., 2003). The increased expression of connexins in vitro and in vivo in response to mechanical stimulation suggests that cells generate enhanced connections with their neighbors enabling proper transmission of mechanical information within the skeletal network, enabling a "syncytium" through the osteocyte network.

The highly interconnected spatial relationship of bone cells has led some to hypothesize that this cellular syncytium may mimic the functions of a neural network (Turner et al., 2002). While bone has generally been considered a non-excitable tissue, there is a growing body of evidence suggesting that membrane excitability may alter mechanoregulation. Ion channels are responsible for maintaining proper electrochemical gradients and thus are sensitive to membrane depolarization. Bone cells express several different ion channels involved in mechanosensitive pathways. These include the gadolinium-sensitive stretch-activated cation channels (Duncan and Hruska, 1994), transient receptor potential (TRP) channels (Abed et al., 2009), and the multimeric voltage sensitive calcium channels (VSCC) (Li et al., 2002; Shao et al., 2005). Stretch-activated cation channels alter membrane potential in response to membrane strain, causing local depolarizations sufficient to activate VSCCs (see Fig. 5). VSCCs have also been shown to be mechanosensitive independent of stretch-activated 
cation channels. Mice treated with the VSCC inhibitors verapamil and nifedipine displayed significantly suppressed load-induced bone formation of the rat tibia (Li et al., 2003). Additionally, VSCCs regulate membrane stretch and shear-induced mechanosensitive events in osteoblasts, and control the release of anabolic signals in response to mechanical stimulation (Rawlinson et al., 1996; Genetos et al., 2005).

While osteoblasts predominantly express the L-type (long lasting) VSCC variant, recent studies demonstrate that the T-type (transient) VSCC is the functional subunit found in osteocytes (Shao et al., 2005; Thompson et al., 2011a). Interestingly, the T-type channel in osteocytes was shown to associate with the membrane-anchored extracellular $a_{2} \delta_{1}$ subunit and this association was important for the regulation of mechanically-induced ATP release (Thompson et al., 2011a). This study defined a new role for the auxiliary $a_{2} \delta_{1}$ subunit in the regulation of mechanosensitive pathways in bone cells.

\section{Intracellular signaling pathways}

Mechanical cues sensed by the cell must ultimately be translated into biochemical signals to illicit changes in signaling events such as phosphorylation, transcription factor translocation or alterations of gene expression. The distal responses associated with many of the mechanotransducers mentioned above include protein kinase cascades, nuclear translocation of regulatory proteins, G-protein regulated messengers, and second messenger systems such as intracellular $\mathrm{Ca}^{2+}$ and cAMP. While mechanical forces are capable of activating nearly every type of signal transduction pathway, we provide here only several examples as models of the many avenues that mechanical signals can use to regulate adaptive responses.

\subsection{Kinase activation - Akt, MAPK, Src, FAK}

Mechanical forces are capable of activating mitogen activated protein kinase (MAPK) cascades in nearly every cell type studied to date. MAPKs are serine/threonine protein kinases essential in differentiation, proliferation, and cell survival. In endothelial cells mechanical factors activate not only ERK1/2 but also p38, BMK-1 and JNK (Yan et al., 1999). ERK1/2 activation, by various types of mechanical stimulation, has been shown to be important in a number of studies in bone cells (Liu et al., 2008; Thompson et al., 2011a).

Mechanical activation of ERK1/2 is necessary for certain strain responses in bone stromal and osteoblastic cells (Rubin et al., 2002). In response to strain, ERK1/2 induces a downregulation of RANKL while upregulating eNOS protein (Rubin et al., 2003). These responses result in decreased osteoclastic potential and enhanced bone formation. Additionally, a recent study demonstrated that activation of ERK1/2 is necessary for TGF $\beta$ induced osteogenic differentiation of MSCs (Arita et al., 2011).

ERK1/2 activation in bone cells has also been associated with mechanical regulation of VSCCs. Fluid shear activation of ERK1/2 in osteoblastic cells requires $\mathrm{Ca}^{2+}$ influx via the VSCCs and is ATP dependent (Liu et al., 2008). In osteocyte-like cells, association of the $a_{2} \delta_{1}$ auxiliary subunit with VSCCs was necessary for mechanical activation of ERK1/2 (see Fig. 5) (Thompson et al., 2011a).

Akt is a serine/threonine kinase that influences a broad range of cellular functions (Manning and Cantley, 2007) and can be activated by various stimuli including growth factors, cytokines as well as mechanical signals. Our lab demonstrated that mechanically activated Akt increased $\beta$-catenin activity, finally resulting in inhibition of MSC adipogenesis (Sen et al., 2008). In this way, mechanically activated Akt signaling alters the lineage allocation of bone marrow MSCs, indicating a mechanism by which mechanical signals might profoundly alter bone morphology. This also suggests that mechanical targeting of Akt might regulate development of cells in other mechanically active environments such as fat and muscle. As 
touched on in section 4.2, increases in focal adhesion assembly are associated with the amplified Akt activation following strain (Sen et al., 2011a). It is worth repeating that the efficacy of loading events is be greatly affected by refractory periods that affect enzyme regeneration, molecule recycling to the surface, as well as the numbers and arrangement of cytoskeletal platforms that initiate the signaling cascade.

Focal adhesion kinase (FAK), a non-receptor cytoplasmic protein tyrosine kinase (PTK), is concentrated near focal adhesions and plays an important role in signaling events involving growth factors, ECM molecules, and stress signals (Schlaepfer et al., 1999). FAK associates with various signaling proteins including Src family PTKs (Orr and Murphy-Ullrich, 2004), phosphatidylinositol 3-kinases (PI3K), and paxillin (Cukierman et al., 2001; Hehlgans et al., 2007). These interactions enable FAK to form a functional network of integrin-stimulated signaling pathways that result in activation of downstream targets including the MAPK pathways (Chatzizacharias et al., 2008). Upon activation, FAK tyrosine 397 is autophosphorylated, generating interactions with src-family proteins and other molecules containing src homology 2 (SH2) domains. Phosphorylation of FAK participates in MAPK activation by interacting with c-src, Grb2, and Ras (Schlaepfer et al., 1999), which is important as most biophysical applications in culture cause activation of MAPK (You et al., 2001a). For instance, oscillatory fluid flow induced a sustained association of Src and FAK with av $\beta 3$ integrin (ibid). Activation of FAK through this integrin association enhanced PI3K activity and modulated downstream ERK and Akt/mTOR/p70S6K pathways that lead to increased osteoblast proliferation. Not surprisingly, FAK has been shown to contribute to oscillatory fluid flow-induced upregulation of osteopontin and COX-2 expression in osteoblasts (Young et al., 2009) and is essential for the fluid shear stress-mediated increases in expression of OCN, Runx2 and Osx, demonstrating the importance of this kinase in osteoblast differentiation and osteogenesis (Wang et al., 2011).

\section{$5.2 \beta$-catenin}

$\beta$-catenin is important in bone biology (Case and Rubin, 2010). A mutation in the Wnt coreceptor Lrp5 leading to a constitutively "on" signal results in high bone mass, demonstrated in several human kindreds (Boyden et al., 2002) and a dominant negative mutation of the same Wnt receptor results in low bone mass (Gong et al., 2001). Robling's laboratory has cemented the role of $\beta$-catenin in both osteoblast and osteocyte function, both as a controller of bone formation and resorption (Cui et al., 2011). Furthermore, loading regulates bone levels of $\beta$-catenin in animals (Armstrong et al., 2007). While the LRP5/6 receptor has been suggested to function in the capacity of a mechanoreceptor in regulating bone mass (Sawakami et al., 2006), it is clear that mechanical input can control MSC lineage decisions through non-LRP5 regulation of $\beta$-catenin. Mechanical strain ( $2 \%, 10$ cycles/min) (Case et al., 2008) as well as both continuous $\left(8\right.$ dynes $\left./ \mathrm{cm}^{2}\right)$ and oscillatory $\left(10\right.$ dynes $\left./ \mathrm{cm}^{2}\right)$ fluid flow, increases active $\beta$-catenin, despite a blocked LRP receptor (Case et al., 2011a). LIV $(<10 \mu \varepsilon, 90 \mathrm{~Hz})$ has a similar effect of enhancing $\beta$-catenin and suppressing adipogenesis, demonstrating that both high and low magnitude mechanical inputs alter MSC fate through $\beta$-catenin (Sen et al., 2011b).

Our lab has further elucidated the non-LRP mechanism by which mechanical strain results in increased cellular levels of active $\beta$-catenin. Through focal adhesion-based connections with the substrate, loading MSCs and osteoblasts results in GSK3 $\beta$ inhibition, leading to protection of $\beta$-catenin from proteosomal degradation (Sen et al., 2009). Proximal signaling causes mechanical activation of mTORC2, which phosphorylates Akt on serine 473, leading to an Akt dependent inhibition of GSK3 $\beta$ (Case et al., 2011b) (see Fig. 6). The emergence of mTORC 2 as a mechanical target suggests a possible further interaction between the cytoskeleton and metabolic responses to exercise as mTORC2 responds to insulin signaling. 


\subsection{GTPases and G-protein coupled receptors}

GTPases are a large family of enzymes that both bind and hydrolyze GTP, in turn functioning as a switch to activate a wide variety of physiological processes. Mechanical input has been shown to activate heterotrimeric GTPases via G-protein coupled receptors, stimulating rises in intracellular calcium, cAMP and cGMP. An interesting example of this type of signaling arises in the generation of nitric oxide after mechanical shear in osteoblasts, which then activates protein kinase G (PKG) (Rangaswami et al., 2009). In this case, PKGII was shown to be necessary for Src activation; PKGII phosphorylates the Src homology 2 domain-containing tyrosine phosphatase 1 (SHP-1) and subsequent fluid shear stress initiated recruitment of PKGII, Src, SHP-1, and SHP-2 to a $\beta 3$ integrin-containing mechanosome (Rangaswami et al., 2010).

Osteocytic cells exposed to fluid shear stress demonstrated a transient decrease in cAMP production (Kwon et al., 2010). cAMP is catalyzed from ATP via adenylate cyclase (AC), an enzyme that is activated by GTPases. AC isoform 6 was found localized to the primary cilium and the decreases in cAMP levels in response to fluid flow were dependent on AC6 activity. Primary cilium-mediated AC6 activation in osteocyte-like cells regulated COX-2 gene expression (Kwon et al., 2010).

Small GTPases, homologous to Ras, are activated during mechanical input (see Fig. 7). RhoA GTPases are activated following mechanical force in a variety of cell types including fibroblasts (Hong et al., 2010), smooth muscle cells (Lim et al., 2010), and in MSCs (Sen et al., 2011a). RhoA primarily acts upon two regulatory proteins Rho-associated, coiled-coil containing protein kinase 1 (ROCK1) and diaphanous homolog 1 (DIAPH1). RhoA has an important role in actin cytoskeletal organization as it regulates stress fiber formation in response to mechanical strain (Chrzanowska-Wodnicka and Burridge, 1996). Interestingly, RhoA was found to be responsible for modulating MSC lineage commitment in response to cell shape: constitutively active RhoA induced osteogenic differentiation while a dominantnegative RhoA cell line committed MSCs to become adipocytes. The RhoA-mediated osteogenic or adipogenic differentiation was dependent on cell shape, where MSCs allowed to adhere to a stable substrate underwent osteogenesis, while rounded MSCs formed adipocytes (Bhadriraju et al., 2007). That RhoA is just one of many examples of these mechanically regulated signaling systems that alter MSC lineage selection and final phenotype underscores the MSC as a critical mechanical target for determining bone morphology.

A recent study activated RhoA using a constant pulling force on a $\beta 1$ integrin-dependent attachment site to delineate those guanine exchange factors (GEFs) responsible for mechanical RhoA activation (Guilluy et al., 2011). GEFs increase RhoA activity by facilitating the exchange of GDP for GTP (Bos et al., 2007). Adhesion complexes are formed on the cell membrane in response to force contained two GEFs, GEF-H1 and leukemia-associated Rho GEF (LARG). Both GEF-H1 and LARG contribute to RhoA activation in response to force albeit through distinct signaling pathways. LARG is activated by Fyn, a member of the Src family of tyrosine protein kinases; while phosphorylation of GEF-H1 in response to mechanical stimuli requires MAPK activation (Guilluy et al., 2011) (see Fig. 7). Cytoskeletal stiffening in response to external mechanical signals likely represents an adaptation that allows a cell to regulate its own mechanically active biochemical system within a mechanical feedback loop.

\subsection{Estrogen Receptor}

The association between menopause and osteoporosis has prompted the investigation of the role of estrogen receptors (ERs) in bone loss. ERa is an important regulator of load-induced 
osteogenesis in vivo (Lee et al., 2003; Callewaert et al., 2010), and in the response of osteoblasts and osteocytes to mechanical stimulation (Aguirre et al., 2007; Armstrong et al., 2007; Sunters et al., 2010). ER does appear to modulate mechanically activated signaling pathways: ERa knockout mice had a reduced response to tibial loading compared to wildtype mice (Lee et al., 2004). As well, the transcriptional response of mouse bones to mechanical loading was severely reduced and delayed in ERa knockout mice compared with wild type littermates, and showed a broad range of effects due to ER deletion (Zaman et al., 2010). Furthermore, three hours following a brief loading regimen, wild type mouse tibiae showed altered transcription of 642 genes while only 26 genes were modified in ERa KO tibiae. Interestingly, expression of the gene encoding sclerostin (Sost), which was significantly reduced after loading in wild type mice, was unaffected in tibiae of loaded ERa KO mice (Zaman et al., 2010).

The role of ERa in bone cell mechanical response is mediated through both genomic and nongenomic actions (Price et al., 2011). Nongenomic actions of ERa involve direct interaction with insulin-like growth factor 1 receptor (IGF-1R), leading to sensitization of IGF-1R and an upregulation of early strain target genes including COX-2 (Liedert et al., 2010). Additionally, expression of $\beta 1$ integrin, which is important for load-induced bone formation, as previously described, can be regulated by ERa. This is also a means whereby estrogen may augment osteogenic target genes in response to mechanical loading (Yeh et al., 2010).

\subsection{Calcium signaling}

A rapid rise in intracellular calcium $\left(\left[\mathrm{Ca}^{2+}\right]_{\mathrm{i}}\right)$ is the earliest detected response in mechanically activated bone cells (Hung et al., 1995) and, as mentioned earlier, calcium channels are important regulators of $\left[\mathrm{Ca}^{2+}\right]_{i}$. Intracellular $\mathrm{Ca}^{2+}$ concentrations are tightly regulated to maintain a very low intracellular level of free $\mathrm{Ca}^{2+}$, thus making an excellent second messenger system, which is especially fitting in a tissue serving as a central reservoir for this important ion, illustrated in Figure 5. $\mathrm{Ca}^{2+}$ serves as an initial signaling event in processes such as proliferation, mitosis, differentiation, and cell motility. Intracellular $\mathrm{Ca}^{2+}$ mobilization is initiated by several different forms of mechanical stimuli, including membrane strain (Walker et al., 2000), pressure (You et al., 2001a), fluid flow (Liu et al., 2008), and osmotic swelling (Thompson et al., 2011a). Interestingly, the frequency of intracellular $\mathrm{Ca}^{2+}$ spiking appears more important to bone cell adaptation in response to load than the magnitude of $\mathrm{Ca}^{2+}$ spikes, and the insertion of a rest period enhanced the $\mathrm{Ca}^{2+}$ response of osteoblastic cells (Donahue et al., 2003). Changes in $\left[\mathrm{Ca}^{2+}\right]_{i}$ have been linked to several different mechanically regulated signaling cascades including IP3 (Chen et al., 2000), ATP (Genetos et al., 2007), and nitric oxide (NO) (McAllister and Frangos, 1999). Intracellular $\mathrm{Ca}^{2+}$ mobilization subsequently stimulates downstream signaling including protein kinase A (PKA) (Ryder and Duncan, 2001), MAPK (Katz et al., 2006), and c-Fos (Chattopadhyay et al., 2007). PGE2 release, shown to be important for mechanical bone formation (Thorsen et al., 1996; Weinreb et al., 1997), was activated by a $\mathrm{Ca}^{2+}$-independent mechanism (Saunders et al., 2003). In contrast, a more recent study demonstrated that PGE2 release was dependent on $\mathrm{Ca}^{2+}$ entry through the L-type VSCC and via release of ATP (Genetos et al., 2005).

\section{Conclusions}

The science underlying mechanotransduction is indeed complex. The key elements include the varied and dynamically changing mechanical environment, the many responsive cells and their manifold sensors of mechanical input, and the multiplicity of stimulated signaling cascades. Nevertheless, from both a basic science standpoint, and the potential to apply this information to the clinic, we must consider that the events that combine to integrate into 
physiologic signaling cascades are critical to achieving and maintaining a structurally suitable skeleton. These essential signals can be initiated through mechanical events at the cell membrane through mechanoreceptors such as integrins, cadherins, ion channels, or primary cilia, as well as through non-matrix associated means such as acceleration moments. During its modulation of skeletal structure, mechanical input alters cell lineage decisions, suggesting that mechanical information, in a modern era where people are more sedentary than they have been in the past, may be key to understanding modern diseases of osteoporosis and obesity (too few osteoblasts, too many adipocytes). While few cycles of high magnitude mechanical events accentuate the peak responses of bone cells, high frequency, low magnitude stimulation also initiates essential signaling events resulting in bone remodeling. These various modes of stimulation activate intracellular signaling pathways such as MAPK, $\beta$-catenin, and GTPase-related events that lead to changes in gene expression and thus cellular adaptation.

Mechanical loading of bone, through normal daily activities or via "prescribed" loading regimens, represents a means of protecting skeletal integrity in a non-pharmacological fashion. Delivering mechanical stimuli to improve or maintain bone health has numerous advantages such that mechanical signals are native to bone, safe at low intensities (Carter et al., 1981), involve the full range of the remodeling cycle, and result in production of lamellar bone (Rubin et al., 1995). Mechanical loading also influences a broad range of tissues, including muscle, tendon, and ligament. As such, mechanical signals may represent an intervention for conditions such as osteoporosis, fall risk, and sarcopenia that integrate numerous physiological systems.

The potential for research into the mechanoresponse of bone is enormous, and the research avenues numerous. The range of mechanical signals, from extremely low to high strain magnitude, frequency, acceleration, duration, and spacing between signals, appear to be important components directing cell response and require better definition. Understanding how mechanical signals regulate a multitude of cells, and control their interactions with other cells and cell types, and interact within wider systems, will need to be addressed experimentally on multiple levels; thus, research on single molecules to single cells to interactive systems to whole animal experiments will be important. Information obtained from clinical studies of endothelial response to vascular dynamics or muscle response to exercise can and should be interpreted in the light of paradigmatic cell response to loads. Understanding how biologic systems respond to these signals could open up a biophysical pharmacopeia. In the future, this biophysical pharmacopoeia may allow physicians to prescribe types and levels of activity directed at bone - or fat or muscle - to regulate high order tissues.

\section{Acknowledgments}

Funding support: work supported by AR056655, AR042360 \& AR043498

\section{Abbreviations}

$\begin{array}{ll}\text { Akt } & \text { protein kinase B } \\ \text { MAPK } & \text { mitogen activated protein kinase } \\ \text { FAK } & \text { focal adhesion kinase } \\ \text { GTPase } & \text { guanine triphosphatase } \\ \text { MSC } & \text { mesenchymal stem cell }\end{array}$




\begin{tabular}{|c|c|}
\hline $1,25(\mathrm{OH})_{2} \mathrm{D}_{3}$ & 1,25 dihydroxy vitamin $\mathrm{D}_{3}$ \\
\hline RANKL & receptor activator of NF kappa B ligand \\
\hline mRNA & messenger RNA \\
\hline GSK3 $\beta$ & glycogen synthase kinase 3 beta \\
\hline mTORC2 & mammalian target of rapamycin complex 2 \\
\hline mTORC & mammalian target of rapamycin complex \\
\hline mTORC1 & mammalian target of rapamycin complex 1 \\
\hline mTOR & mammalian target of rapamycin \\
\hline$\mu \varepsilon$ & microstrain \\
\hline $\mathrm{PGE}_{2}$ & prostaglandin $\mathrm{E}_{2}$ \\
\hline $\mathbf{A T P}$ & adenosine triphosphate \\
\hline COX-2 & cyclooxygenase 2 \\
\hline LMMS & low magnitude mechanical stimulation \\
\hline LIV & low intensity vibration \\
\hline$\mu \mathbf{C T}$ & micro computed tomography \\
\hline LCS & lacuna-canalicular system \\
\hline ECM & extracellular matrix \\
\hline GEF & guanine exchange factor \\
\hline GTP & guanine triphosphate \\
\hline GDP & guanine diphosphate \\
\hline ERK1/2 & extracellular signal-regulated kinases $1 / 2$ \\
\hline PCD & primary ciliary dyskinesia \\
\hline PC1 & polycystin 1 \\
\hline PC2 & polycystin 2 \\
\hline STAT6 & signal transducer and activator of transcription 6 \\
\hline сAMP & cyclic adenosine monophosphate \\
\hline PKA & protein kinase $\mathrm{A}$ \\
\hline PI3K & phosphoinositide 3-kinase \\
\hline Cx43 & connexin 43 \\
\hline TRP & transient receptor potential \\
\hline VSCC & voltage sensitive calcium channel \\
\hline JNK & c-Jun N-terminal kinases \\
\hline ВМK-1 & beta cell myeloid kinase-1 \\
\hline eNOS & endothelial nitric oxide synthase \\
\hline TGF $\beta$ & transforming growth factor beta \\
\hline PTK & protein tyrosine kinase \\
\hline
\end{tabular}




\begin{tabular}{|c|c|}
\hline SH2 & Src homology 2 domain \\
\hline c-Src & chicken sarcoma gene \\
\hline Grb2 & growth factor receptor-bound protein 2 \\
\hline Ras & rat sarcoma gene \\
\hline OCN & osteocalcin \\
\hline Runx2 & core binding factor subunit alpha- 1 \\
\hline Osx & osterix \\
\hline cGMP & cyclic guanine monophosphate \\
\hline PK6 & protein kinase 6 \\
\hline SHP-1 & small heterodimer partner 1 \\
\hline $\mathbf{A C}$ & adenylate cyclase \\
\hline RhoA & ras homolog gene family member $\mathrm{A}$ \\
\hline ROCK1 & Rho-associated, coiled-coil containing protein kinase 1 \\
\hline DIAPH1 & diaphanous homolog 1 \\
\hline GDP & guanine diphosphate \\
\hline GTP & guanine triphosphate \\
\hline GEF-H1 & guanine exchange factor, $\mathrm{H} 1$ \\
\hline LARG & Leukemia-associated Rho guanine nucleotide exchange factor \\
\hline $\mathbf{E R}$ & estrogen receptor \\
\hline Sost & sclerostin gene \\
\hline KO & knock out \\
\hline IGF-1R & insulin-like growth factor 1 receptor \\
\hline$\left[\mathrm{Ca}^{2+}\right]_{\mathbf{i}}$ & intracellular calcium concentration \\
\hline PKA & protein kinase $\mathrm{A}$ \\
\hline$\beta$-cat & beta catenin \\
\hline
\end{tabular}

\section{References}

Abed E, Labelle D, Martineau C, Loghin A, Moreau R. Expression of transient receptor potential (TRP) channels in human and murine osteoblast-like cells. Molecular membrane biology. 2009; 26:146-58. [PubMed: 19115145]

Adachi T, Aonuma Y, Tanaka M, Hojo M, Takano-Yamamoto T, Kamioka H. Calcium response in single osteocytes to locally applied mechanical stimulus: differences in cell process and cell body. Journal of biomechanics. 2009; 42:1989-95. [PubMed: 19625024]

Adams DJ, Spirt AA, Brown TD, Fritton SP, Rubin CT, Brand RA. Testing the daily stress stimulus theory of bone adaptation with natural and experimentally controlled strain histories. Journal of biomechanics. 1997; 30:671-8. [PubMed: 9239546]

Aguirre JI, Plotkin LI, Gortazar AR, Millan MM, O'Brien CA, Manolagas SC, Bellido T. A novel ligand-independent function of the estrogen receptor is essential for osteocyte and osteoblast mechanotransduction. The Journal of biological chemistry. 2007; 282:25501-8. [PubMed: 17609204] 
Aikawa R, Nagai T, Kudoh S, Zou Y, Tanaka M, Tamura M, Akazawa H, Takano H, Nagai R, Komuro I. Integrins play a critical role in mechanical stress-induced p38 MAPK activation. Hypertension. 2002; 39:233-8. [PubMed: 11847190]

Alford AI, Jacobs CR, Donahue HJ. Oscillating fluid flow regulates gap junction communication in osteocytic MLO-Y4 cells by an ERK1/2 MAP kinase-dependent mechanism small star, filled. Bone. 2003; 33:64-70. [PubMed: 12919700]

Anderson RG. The caveolae membrane system. Annual review of biochemistry. 1998; 67:199-225.

Arita NA, Pelaez D, Cheung HS. Activation of the extracellular signal-regulated kinases 1 and 2 (ERK1/2) is needed for the TGFbeta-induced chondrogenic and osteogenic differentiation of mesenchymal stem cells. Biochemical and biophysical research communications. 2011; 405:564-9. [PubMed: 21262199]

Armstrong VJ, Muzylak M, Sunters A, Zaman G, Saxon LK, Price JS, Lanyon LE. Wnt/beta-catenin signaling is a component of osteoblastic bone cell early responses to load-bearing and requires estrogen receptor alpha. The Journal of biological chemistry. 2007; 282:20715-27. [PubMed: 17491024]

Arnsdorf EJ, Tummala P, Kwon RY, Jacobs CR. Mechanically induced osteogenic differentiation--the role of RhoA, ROCKII and cytoskeletal dynamics. Journal of cell science. 2009; 122:546-53. [PubMed: 19174467]

Bacabac RG, Smit TH, Heethaar RM, van Loon JJ, Pourquie MJ, Nieuwstadt FT, Klein-Nulend J. Characteristics of the parallel-plate flow chamber for mechanical stimulation of bone cells under microgravity. Journal of gravitational physiology : a journal of the International Society for Gravitational Physiology. 2002; 9:P181-2. [PubMed: 19180754]

Berbari NF, O'Connor AK, Haycraft CJ, Yoder BK. The primary cilium as a complex signaling center. Current biology : CB. 2009; 19:R526-35. [PubMed: 19602418]

Bhadriraju K, Yang M, Alom Ruiz S, Pirone D, Tan J, Chen CS. Activation of ROCK by RhoA is regulated by cell adhesion, shape, and cytoskeletal tension. Experimental cell research. 2007; 313:3616-23. [PubMed: 17673200]

Bidwell JP, Pavalko FM. The Load-Bearing Mechanosome Revisited. Clinical reviews in bone and mineral metabolism. 2010; 8:213-223. [PubMed: 21479153]

Bonewald LF. The amazing osteocyte. Journal of bone and mineral research : the official journal of the American Society for Bone and Mineral Research. 2011; 26:229-38. [PubMed: 21254230]

Bos JL, Rehmann H, Wittinghofer A. GEFs and GAPs: critical elements in the control of small G proteins. Cell. 2007; 129:865-77. [PubMed: 17540168]

Boyden LM, Mao J, Belsky J, Mitzner L, Farhi A, Mitnick MA, Wu D, Insogna K, Lifton RP. High bone density due to a mutation in LDL-receptor-related protein 5. The New England journal of medicine. 2002; 346:1513-21. [PubMed: 12015390]

Callewaert F, Bakker A, Schrooten J, Van Meerbeek B, Verhoeven G, Boonen S, Vanderschueren D. Androgen receptor disruption increases the osteogenic response to mechanical loading in male mice. Journal of bone and mineral research : the official journal of the American Society for Bone and Mineral Research. 2010; 25:124-31. [PubMed: 19821763]

Carmeliet G, Vico L, Bouillon R. Space flight: a challenge for normal bone homeostasis. Critical reviews in eukaryotic gene expression. 2001; 11:131-44. [PubMed: 11693958]

Carter DR, Caler WE, Spengler DM, Frankel VH. Fatigue behavior of adult cortical bone: the influence of mean strain and strain range. Acta orthopaedica Scandinavica. 1981; 52:481-90. [PubMed: 7331784]

Case N, Ma M, Sen B, Xie Z, Gross TS, Rubin J. Beta-catenin levels influence rapid mechanical responses in osteoblasts. The Journal of biological chemistry. 2008; 283:29196-205. [PubMed: 18723514]

Case N, Rubin J. Beta-catenin--a supporting role in the skeleton. Journal of cellular biochemistry. 2010; 110:545-53. [PubMed: 20512915]

Case N, Sen B, Thomas JA, Styner M, Xie Z, Jacobs CR, Rubin J. Steady and oscillatory fluid flows produce a similar osteogenic phenotype. Calcified tissue international. 2011a; 88:189-97. [PubMed: 21165611] 
Case N, Thomas J, Sen B, Styner M, Xie Z, Galior K, Rubin J. Mechanical Regulation of Glycogen Synthase Kinase 3beta (GSK3beta) in Mesenchymal Stem Cells Is Dependent on Akt Protein Serine 473 Phosphorylation via mTORC2 Protein. The Journal of biological chemistry. 2011b; 286:39450-6. [PubMed: 21956113]

Case N, Xie Z, Sen B, Styner M, Zou M, O'Conor C, Horowitz M, Rubin J. Mechanical activation of beta-catenin regulates phenotype in adult murine marrow-derived mesenchymal stem cells. Journal of orthopaedic research : official publication of the Orthopaedic Research Society. 2010; 28:15318. [PubMed: 20872592]

Chaible LM, Sanches DS, Cogliati B, Mennecier G, Zaidan Dagli MLDMP. Delayed Osteoblastic Differentiation and Bone Development in Cx43 Knockout Mice. Toxicologic pathology. 2011

Chalfie M. Neurosensory mechanotransduction. Nature reviews. Molecular cell biology. 2009; 10:4452.

Chattopadhyay N, Quinn SJ, Kifor O, Ye C, Brown EM. The calcium-sensing receptor $(\mathrm{CaR})$ is involved in strontium ranelate-induced osteoblast proliferation. Biochemical pharmacology. 2007; 74:438-47. [PubMed: 17531955]

Chatzizacharias NA, Kouraklis GP, Theocharis SE. Disruption of FAK signaling: a side mechanism in cytotoxicity. Toxicology. 2008; 245:1-10. [PubMed: 18215454]

Chen CS, Alonso JL, Ostuni E, Whitesides GM, Ingber DE. Cell shape provides global control of focal adhesion assembly. Biochemical and biophysical research communications. 2003; 307:355-61. [PubMed: 12859964]

Chen NX, Ryder KD, Pavalko FM, Turner CH, Burr DB, Qiu J, Duncan RL. Ca(2+) regulates fluid shear-induced cytoskeletal reorganization and gene expression in osteoblasts. American journal of physiology. Cell physiology. 2000; 278:C989-97. [PubMed: 10794673]

Chrzanowska-Wodnicka M, Burridge K. Rho-stimulated contractility drives the formation of stress fibers and focal adhesions. The Journal of cell biology. 1996; 133:1403-15. [PubMed: 8682874]

Cowin SC, Weinbaum S. Strain amplification in the bone mechanosensory system. The American journal of the medical sciences. 1998; 316:184-8. [PubMed: 9749560]

Cowin SC, Weinbaum S, Zeng Y. A case for bone canaliculi as the anatomical site of strain generated potentials. Journal of biomechanics. 1995; 28:1281-97. [PubMed: 8522542]

Cui Y, Niziolek PJ, MacDonald BT, Zylstra CR, Alenina N, Robinson DR, Zhong Z, Matthes S, Jacobsen CM, Conlon RA, Brommage R, Liu Q, Mseeh F, Powell DR, Yang QM, Zambrowicz B, Gerrits H, Gossen JA, He X, Bader M, Williams BO, Warman ML, Robling AG. Lrp5 functions in bone to regulate bone mass. Nature medicine. 2011; 17:684-91.

Cukierman E, Pankov R, Stevens DR, Yamada KM. Taking cell-matrix adhesions to the third dimension. Science. 2001; 294:1708-12. [PubMed: 11721053]

Dahl KN, Kalinowski A, Pekkan K. Mechanobiology and the microcirculation: cellular, nuclear and fluid mechanics. Microcirculation. 2010; 17:179-91. [PubMed: 20374482]

David V, Martin A, Lafage-Proust MH, Malaval L, Peyroche S, Jones DB, Vico L, Guignandon A. Mechanical loading down-regulates peroxisome proliferator-activated receptor gamma in bone marrow stromal cells and favors osteoblastogenesis at the expense of adipogenesis. Endocrinology. 2007; 148:2553-62. [PubMed: 17317771]

del Rio A, Perez-Jimenez R, Liu R, Roca-Cusachs P, Fernandez JM, Sheetz MP. Stretching single talin rod molecules activates vinculin binding. Science. 2009; 323:638-41. [PubMed: 19179532]

Dillaman RM, Roer RD, Gay DM. Fluid movement in bone: theoretical and empirical. Journal of biomechanics. 1991; 24(Suppl 1):163-77. [PubMed: 1791176]

Donahue SW, Donahue HJ, Jacobs CR. Osteoblastic cells have refractory periods for fluid-flowinduced intracellular calcium oscillations for short bouts of flow and display multiple lowmagnitude oscillations during long-term flow. Journal of biomechanics. 2003; 36:35-43. [PubMed: 12485636]

Duncan RL, Hruska KA. Chronic, intermittent loading alters mechanosensitive channel characteristics in osteoblast-like cells. The American journal of physiology. 1994; 267:F909-16. [PubMed: 7528987]

Farach-Carson MC, Carson DD. Perlecan--a multifunctional extracellular proteoglycan scaffold. Glycobiology. 2007; 17:897-905. [PubMed: 17442708] 
Federman M, Nichols G Jr. Bone cell cilia: vestigial or functional organelles? Calcified tissue research. 1974; 17:81-5. [PubMed: 4451879]

Ferraro JT, Daneshmand M, Bizios R, Rizzo V. Depletion of plasma membrane cholesterol dampens hydrostatic pressure and shear stress-induced mechanotransduction pathways in osteoblast cultures. American journal of physiology. Cell physiology. 2004; 286:C831-9. [PubMed: 14644772]

Friedland JC, Lee MH, Boettiger D. Mechanically activated integrin switch controls alpha5beta1 function. Science. 2009; 323:642-4. [PubMed: 19179533]

Fritton SP, McLeod KJ, Rubin CT. Quantifying the strain history of bone: spatial uniformity and selfsimilarity of low-magnitude strains. Journal of biomechanics. 2000; 33:317-25. [PubMed: 10673115]

Frost HM. The skeletal intermediary organization. Metabolic bone disease \& related research. 1983; 4:281-90.

Gardinier JD, Majumdar S, Duncan RL, Wang L. Cyclic Hydraulic Pressure and Fluid Flow Differentially Modulate Cytoskeleton Re-Organization in MC3T3 Osteoblasts. Cellular and molecular bioengineering. 2009; 2:133-143. [PubMed: 20161062]

Gardinier JD, Townend CW, Jen KP, Wu Q, Duncan RL, Wang L. In situ permeability measurement of the mammalian lacunar-canalicular system. Bone. 2010; 46:1075-81. [PubMed: 20080221]

Genetos DC, Geist DJ, Liu D, Donahue HJ, Duncan RL. Fluid shear-induced ATP secretion mediates prostaglandin release in MC3T3-E1 osteoblasts. Journal of bone and mineral research : the official journal of the American Society for Bone and Mineral Research. 2005; 20:41-9. [PubMed: 15619668]

Genetos DC, Kephart CJ, Zhang Y, Yellowley CE, Donahue HJ. Oscillating fluid flow activation of gap junction hemichannels induces ATP release from MLO-Y4 osteocytes. Journal of cellular physiology. 2007; 212:207-14. [PubMed: 17301958]

Globus RK, Bikle DD, Morey-Holton E. The temporal response of bone to unloading. Endocrinology. 1986; 118:733-42. [PubMed: 3943489]

Goncalves I, Nesbitt WS, Yuan Y, Jackson SP. Importance of temporal flow gradients and integrin alphaIIbbeta3 mechanotransduction for shear activation of platelets. The Journal of biological chemistry. 2005; 280:15430-7. [PubMed: 15701653]

Gong Y, Slee RB, Fukai N, Rawadi G, Roman-Roman S, Reginato AM, Wang H, Cundy T, Glorieux FH, Lev D, Zacharin M, Oexle K, Marcelino J, Suwairi W, Heeger S, Sabatakos G, Apte S, Adkins WN, Allgrove J, Arslan-Kirchner M, Batch JA, Beighton P, Black GC, Boles RG, Boon LM, Borrone C, Brunner HG, Carle GF, Dallapiccola B, De Paepe A, Floege B, Halfhide ML, Hall B, Hennekam RC, Hirose T, Jans A, Juppner H, Kim CA, Keppler-Noreuil K, Kohlschuetter A, LaCombe D, Lambert M, Lemyre E, Letteboer T, Peltonen L, Ramesar RS, Romanengo M, Somer H, Steichen-Gersdorf E, Steinmann B, Sullivan B, Superti-Furga A, Swoboda W, van den Boogaard MJ, Van Hul W, Vikkula M, Votruba M, Zabel B, Garcia T, Baron R, Olsen BR, Warman ML. LDL receptor-related protein 5 (LRP5) affects bone accrual and eye development. Cell. 2001; 107:513-23. [PubMed: 11719191]

Gradilone SA, Masyuk AI, Splinter PL, Banales JM, Huang BQ, Tietz PS, Masyuk TV, Larusso NF. Cholangiocyte cilia express TRPV4 and detect changes in luminal tonicity inducing bicarbonate secretion. Proceedings of the National Academy of Sciences of the United States of America. 2007; 104:19138-43. [PubMed: 18024594]

Graziano F, Humar B, Guilford P. The role of the E-cadherin gene (CDH1) in diffuse gastric cancer susceptibility: from the laboratory to clinical practice. Annals of oncology : official journal of the European Society for Medical Oncology/ESMO. 2003; 14:1705-13. [PubMed: 14630673]

Griffin XL, Costa ML, Parsons N, Smith N. Electromagnetic field stimulation for treating delayed union or non-union of long bone fractures in adults. Cochrane database of systematic reviews. 2011:CD008471.

Gross TS, Srinivasan S, Liu CC, Clemens TL, Bain SD. Noninvasive loading of the murine tibia: an in vivo model for the study of mechanotransduction. Journal of bone and mineral research : the official journal of the American Society for Bone and Mineral Research. 2002; 17:493-501. [PubMed: 11874240] 
Guilluy C, Swaminathan V, Garcia-Mata R, O'Brien ET, Superfine R, Burridge K. The Rho GEFs LARG and GEF-H1 regulate the mechanical response to force on integrins. Nature cell biology. $2011 ; 13: 722-7$.

Han Y, Cowin SC, Schaffler MB, Weinbaum S. Mechanotransduction and strain amplification in osteocyte cell processes. Proceedings of the National Academy of Sciences of the United States of America. 2004; 101:16689-94. [PubMed: 15539460]

Heckman JD, Ryaby JP, McCabe J, Frey JJ, Kilcoyne RF. Acceleration of tibial fracture-healing by non-invasive, low-intensity pulsed ultrasound. The Journal of bone and joint surgery. American volume. 1994; 76:26-34. [PubMed: 8288661]

Hehlgans S, Haase M, Cordes N. Signalling via integrins: implications for cell survival and anticancer strategies. Biochimica et biophysica acta. 2007; 1775:163-80. [PubMed: 17084981]

Hert J, Liskova M, Landa J. Reaction of bone to mechanical stimuli. 1. Continuous and intermittent loading of tibia in rabbit. Folia morphologica. 1971; 19:290-300. [PubMed: 5142775]

Hoey DA, Kelly DJ, Jacobs CR. A role for the primary cilium in paracrine signaling between mechanically stimulated osteocytes and mesenchymal stem cells. Biochemical and biophysical research communications. 2011; 412:182-7. [PubMed: 21810408]

Hong SY, Jeon YM, Lee HJ, Kim JG, Baek JA, Lee JC. Activation of RhoA and FAK induces ERKmediated osteopontin expression in mechanical force-subjected periodontal ligament fibroblasts. Molecular and cellular biochemistry. 2010; 335:263-72. [PubMed: 19798549]

Horwitz A, Duggan K, Buck C, Beckerle MC, Burridge K. Interaction of plasma membrane fibronectin receptor with talin--a transmembrane linkage. Nature. 1986; 320:531-3. [PubMed: 2938015]

Huang RP, Rubin CT, McLeod KJ. Changes in postural muscle dynamics as a function of age. The journals of gerontology. Series A, Biological sciences and medical sciences. 1999; 54:B352-7.

Hung CT, Pollack SR, Reilly TM, Brighton CT. Real-time calcium response of cultured bone cells to fluid flow. Clinical orthopaedics and related research. 1995:256-69. [PubMed: 7641488]

Ingber DE. Cellular mechanotransduction: putting all the pieces together again. The FASEB journal : official publication of the Federation of American Societies for Experimental Biology. 2006; 20:811-27.

Judex S, Garman R, Squire M, Donahue LR, Rubin C. Genetically based influences on the site-specific regulation of trabecular and cortical bone morphology. Journal of bone and mineral research : the official journal of the American Society for Bone and Mineral Research. 2004; 19:600-6. [PubMed: 15005847]

Kannus P, Haapasalo H, Sievanen H, Oja P, Vuori I. The site-specific effects of long-term unilateral activity on bone mineral density and content. Bone. 1994a; 15:279-84. [PubMed: 8068448]

Kannus P, Jarvinen M, Sievanen H, Oja P, Vuori I. Osteoporosis in men with a history of tibial fracture. Journal of bone and mineral research : the official journal of the American Society for Bone and Mineral Research. 1994b; 9:423-9. [PubMed: 8191937]

Kapur S, Baylink DJ, Lau KH. Fluid flow shear stress stimulates human osteoblast proliferation and differentiation through multiple interacting and competing signal transduction pathways. Bone. 2003; 32:241-51. [PubMed: 12667551]

Karlsson MK, Johnell O, Obrant KJ. Bone mineral density in weight lifters. Calcified tissue international. 1993; 52:212-5. [PubMed: 8481835]

Katsumi A, Orr AW, Tzima E, Schwartz MA. Integrins in mechanotransduction. The Journal of biological chemistry. 2004; 279:12001-4. [PubMed: 14960578]

Katz S, Boland R, Santillan G. Modulation of ERK 1/2 and p38 MAPK signaling pathways by ATP in osteoblasts: involvement of mechanical stress-activated calcium influx, PKC and Src activation. The international journal of biochemistry \& cell biology. 2006; 38:2082-91.

Krasnoff J, Painter P. The physiological consequences of bed rest and inactivity. Advances in renal replacement therapy. 1999; 6:124-32. [PubMed: 10230879]

Kwon RY, Temiyasathit S, Tummala P, Quah CC, Jacobs CR. Primary cilium-dependent mechanosensing is mediated by adenylyl cyclase 6 and cyclic AMP in bone cells. The FASEB journal : official publication of the Federation of American Societies for Experimental Biology. 2010; 24:2859-68. 
Lajoie P, Goetz JG, Dennis JW, Nabi IR. Lattices, rafts, and scaffolds: domain regulation of receptor signaling at the plasma membrane. The Journal of cell biology. 2009; 185:381-5. [PubMed: 19398762]

Lang T, LeBlanc A, Evans H, Lu Y, Genant H, Yu A. Cortical and trabecular bone mineral loss from the spine and hip in long-duration spaceflight. Journal of bone and mineral research : the official journal of the American Society for Bone and Mineral Research. 2004; 19:1006-12. [PubMed: 15125798]

Lanyon LE, Rubin CT. Static vs dynamic loads as an influence on bone remodelling. Journal of biomechanics. 1984; 17:897-905. [PubMed: 6520138]

LeBlanc A, Schneider V, Shackelford L, West S, Oganov V, Bakulin A, Voronin L. Bone mineral and lean tissue loss after long duration space flight. Journal of musculoskeletal \& neuronal interactions. 2000; 1:157-60. [PubMed: 15758512]

Lee K, Jessop H, Suswillo R, Zaman G, Lanyon L. Endocrinology: bone adaptation requires oestrogen receptor-alpha. Nature. 2003; 424:389. [PubMed: 12879058]

Lee KC, Jessop H, Suswillo R, Zaman G, Lanyon LE. The adaptive response of bone to mechanical loading in female transgenic mice is deficient in the absence of oestrogen receptor-alpha and -beta. The Journal of endocrinology. 2004; 182:193-201. [PubMed: 15283680]

Levenberg S, Yarden A, Kam Z, Geiger B. p27 is involved in N-cadherin-mediated contact inhibition of cell growth and S-phase entry. Oncogene. 1999; 18:869-76. [PubMed: 10023662]

Li J, Duncan RL, Burr DB, Gattone VH, Turner CH. Parathyroid hormone enhances mechanically induced bone formation, possibly involving L-type voltage-sensitive calcium channels. Endocrinology. 2003; 144:1226-33. [PubMed: 12639904]

Li J, Duncan RL, Burr DB, Turner CH. L-type calcium channels mediate mechanically induced bone formation in vivo. Journal of bone and mineral research : the official journal of the American Society for Bone and Mineral Research. 2002; 17:1795-800. [PubMed: 12369783]

Liedert A, Wagner L, Seefried L, Ebert R, Jakob F, Ignatius A. Estrogen receptor and Wnt signaling interact to regulate early gene expression in response to mechanical strain in osteoblastic cells. Biochemical and biophysical research communications. 2010; 394:755-9. [PubMed: 20227388]

Lim SM, Kreipe BA, Trzeciakowski J, Dangott L, Trache A. Extracellular matrix effect on RhoA signaling modulation in vascular smooth muscle cells. Experimental cell research. 2010; 316:2833-48. [PubMed: 20599954]

Litzenberger JB, Kim JB, Tummala P, Jacobs CR. Beta1 integrins mediate mechanosensitive signaling pathways in osteocytes. Calcified tissue international. 2010; 86:325-32. [PubMed: 20213106]

Liu D, Genetos DC, Shao Y, Geist DJ, Li J, Ke HZ, Turner CH, Duncan RL. Activation of extracellular-signal regulated kinase (ERK1/2) by fluid shear is $\mathrm{Ca}(2+)$ - and ATP-dependent in MC3T3-E1 osteoblasts. Bone. 2008; 42:644-52. [PubMed: 18291742]

Low SH, Vasanth S, Larson CH, Mukherjee S, Sharma N, Kinter MT, Kane ME, Obara T, Weimbs T. Polycystin-1, STAT6, and P100 function in a pathway that transduces ciliary mechanosensation and is activated in polycystic kidney disease. Developmental cell. 2006; 10:57-69. [PubMed: 16399078]

Lyritis GP, Georgoulas T, Zafeiris CP. Bone anabolic versus bone anticatabolic treatment of postmenopausal osteoporosis. Annals of the New York Academy of Sciences. 2010; 1205:277-83. [PubMed: 20840284]

MacKelvie KJ, Khan KM, Petit MA, Janssen PA, McKay HA. A school-based exercise intervention elicits substantial bone health benefits: a 2-year randomized controlled trial in girls. Pediatrics. 2003; 112:e447. [PubMed: 14654643]

Makrigiannakis A, Coukos G, Christofidou-Solomidou M, Gour BJ, Radice GL, Blaschuk O, Coutifaris C. N-cadherin-mediated human granulosa cell adhesion prevents apoptosis: a role in follicular atresia and luteolysis? The American journal of pathology. 1999; 154:1391-406. [PubMed: 10329592]

Malone AM, Anderson CT, Tummala P, Kwon RY, Johnston TR, Stearns T, Jacobs CR. Primary cilia mediate mechanosensing in bone cells by a calcium-independent mechanism. Proceedings of the National Academy of Sciences of the United States of America. 2007a; 104:13325-30. [PubMed: 17673554] 
Malone AM, Batra NN, Shivaram G, Kwon RY, You L, Kim CH, Rodriguez J, Jair K, Jacobs CR. The role of actin cytoskeleton in oscillatory fluid flow-induced signaling in MC3T3-E1 osteoblasts. American journal of physiology. Cell physiology. 2007b; 292:C1830-6. [PubMed: 17251324]

Manning BD, Cantley LC. AKT/PKB signaling: navigating downstream. Cell. 2007; 129:1261-74. [PubMed: 17604717]

Martin TJ, Allan EH, Ho PW, Gooi JH, Quinn JM, Gillespie MT, Krasnoperov V, Sims NA. Communication between ephrinB2 and EphB4 within the osteoblast lineage. Advances in experimental medicine and biology. 2010; 658:51-60. [PubMed: 19950015]

McAllister TN, Frangos JA. Steady and transient fluid shear stress stimulate NO release in osteoblasts through distinct biochemical pathways. Journal of bone and mineral research : the official journal of the American Society for Bone and Mineral Research. 1999; 14:930-6. [PubMed: 10352101]

McBeath R, Pirone DM, Nelson CM, Bhadriraju K, Chen CS. Cell shape, cytoskeletal tension, and RhoA regulate stem cell lineage commitment. Developmental cell. 2004; 6:483-95. [PubMed: 15068789]

McNamara LM, Majeska RJ, Weinbaum S, Friedrich V, Schaffler MB. Attachment of osteocyte cell processes to the bone matrix. Anatomical record. 2009; 292:355-63.

Meyers VE, Zayzafoon M, Douglas JT, McDonald JM. RhoA and cytoskeletal disruption mediate reduced osteoblastogenesis and enhanced adipogenesis of human mesenchymal stem cells in modeled microgravity. Journal of bone and mineral research : the official journal of the American Society for Bone and Mineral Research. 2005; 20:1858-66. [PubMed: 16160744]

Millward-Sadler SJ, Salter DM. Integrin-dependent signal cascades in chondrocyte mechanotransduction. Annals of biomedical engineering. 2004; 32:435-46. [PubMed: 15095818]

Modlesky CM, Majumdar S, Narasimhan A, Dudley GA. Trabecular bone microarchitecture is deteriorated in men with spinal cord injury. Journal of bone and mineral research : the official journal of the American Society for Bone and Mineral Research. 2004; 19:48-55. [PubMed: 14753736]

Morris CE. Mechanosensitive ion channels. The Journal of membrane biology. 1990; 113:93-107. [PubMed: 1690807]

Mosley JR, March BM, Lynch J, Lanyon LE. Strain magnitude related changes in whole bone architecture in growing rats. Bone. 1997; 20:191-8. [PubMed: 9071468]

Moustafa A, Sugiyama T, Prasad J, Zaman G, Gross TS, Lanyon LE, Price JS. Mechanical loadingrelated changes in osteocyte sclerostin expression in mice are more closely associated with the subsequent osteogenic response than the peak strains engendered. Osteoporosis international : a journal established as result of cooperation between the European Foundation for Osteoporosis and the National Osteoporosis Foundation of the USA. 2011

Murray DW, Rushton N. The effect of strain on bone cell prostaglandin E2 release: a new experimental method. Calcif Tissue Int. 1990; 47:35-9. [PubMed: 2369689]

Myers KA, Rattner JB, Shrive NG, Hart DA. Osteoblast-like cells and fluid flow: cytoskeletondependent shear sensitivity. Biochemical and biophysical research communications. 2007; 364:214-9. [PubMed: 17942076]

Nelson WJ, Nusse R. Convergence of Wnt, beta-catenin, and cadherin pathways. Science. 2004; 303:1483-7. [PubMed: 15001769]

Norvell SM, Alvarez M, Bidwell JP, Pavalko FM. Fluid shear stress induces beta-catenin signaling in osteoblasts. Calcified tissue international. 2004; 75:396-404. [PubMed: 15592796]

O'Connor JA, Lanyon LE, MacFie H. The influence of strain rate on adaptive bone remodelling. Journal of biomechanics. 1982; 15:767-81. [PubMed: 7153230]

Olsen B. Nearly all cells in vertebrates and many cells in invertebrates contain primary cilia. Matrix biology : journal of the International Society for Matrix Biology. 2005; 24:449-50. [PubMed: 16226676]

Orr AW, Murphy-Ullrich JE. Regulation of endothelial cell function BY FAK and PYK2. Frontiers in bioscience : a journal and virtual library. 2004; 9:1254-66. [PubMed: 14977542]

Ozawa H, Imamura K, Abe E, Takahashi N, Hiraide T, Shibasaki Y, Fukuhara T, Suda T. Effect of a continuously applied compressive pressure on mouse osteoblast-like cells (MC3T3-E1) in vitro. Journal of cellular physiology. 1990; 142:177-85. [PubMed: 2298821] 
Ozcivici E, Luu YK, Adler B, Qin YX, Rubin J, Judex S, Rubin CT. Mechanical signals as anabolic agents in bone. Nature reviews. Rheumatology. 2010; 6:50-9.

Pavalko FM, Chen NX, Turner CH, Burr DB, Atkinson S, Hsieh YF, Qiu J, Duncan RL. Fluid shearinduced mechanical signaling in MC3T3-E1 osteoblasts requires cytoskeleton-integrin interactions. The American journal of physiology. 1998; 275:C1591-601. [PubMed: 9843721]

Piekarski K, Munro M. Transport mechanism operating between blood supply and osteocytes in long bones. Nature. 1977; 269:80-2. [PubMed: 895891]

Praetorius HA, Spring KR. Removal of the MDCK cell primary cilium abolishes flow sensing. The Journal of membrane biology. 2003; 191:69-76. [PubMed: 12532278]

Price JS, Sugiyama T, Galea GL, Meakin LB, Sunters A, Lanyon LE. Role of endocrine and paracrine factors in the adaptation of bone to mechanical loading. Current osteoporosis reports. 2011; 9:76-82. [PubMed: 21384138]

Puel JL. Chemical synaptic transmission in the cochlea. Progress in neurobiology. 1995; 47:449-76. [PubMed: 8787031]

Qin YX, Lam H. Intramedullary pressure and matrix strain induced by oscillatory skeletal muscle stimulation and its potential in adaptation. Journal of biomechanics. 2009; 42:140-5. [PubMed: 19081096]

Qin YX, Rubin CT, McLeod KJ. Nonlinear dependence of loading intensity and cycle number in the maintenance of bone mass and morphology. Journal of orthopaedic research : official publication of the Orthopaedic Research Society. 1998; 16:482-9. [PubMed: 9747791]

Radel C, Carlile-Klusacek M, Rizzo V. Participation of caveolae in beta1 integrin-mediated mechanotransduction. Biochemical and biophysical research communications. 2007; 358:62631. [PubMed: 17498653]

Rangaswami H, Marathe N, Zhuang S, Chen Y, Yeh JC, Frangos JA, Boss GR, Pilz RB. Type II cGMP-dependent protein kinase mediates osteoblast mechanotransduction. The Journal of biological chemistry. 2009; 284:14796-808. [PubMed: 19282289]

Rangaswami H, Schwappacher R, Marathe N, Zhuang S, Casteel DE, Haas B, Chen Y, Pfeifer A, Kato H, Shattil S, Boss GR, Pilz RB. Cyclic GMP and protein kinase G control a Src-containing mechanosome in osteoblasts. Science signaling. 2010; 3:ra91. [PubMed: 21177494]

Rawlinson SC, Pitsillides AA, Lanyon LE. Involvement of different ion channels in osteoblasts' and osteocytes' early responses to mechanical strain. Bone. 1996; 19:609-14. [PubMed: 8968027]

Reedquist KA, Ross E, Koop EA, Wolthuis RM, Zwartkruis FJ, van Kooyk Y, Salmon M, Buckley CD, Bos JL. The small GTPase, Rap1, mediates CD31-induced integrin adhesion. The Journal of cell biology. 2000; 148:1151-8. [PubMed: 10725328]

Robling AG, Hinant FM, Burr DB, Turner CH. Improved bone structure and strength after long-term mechanical loading is greatest if loading is separated into short bouts. Journal of bone and mineral research : the official journal of the American Society for Bone and Mineral Research. 2002; 17:1545-54. [PubMed: 12162508]

Rubin C, Gross T, Qin YX, Fritton S, Guilak F, McLeod K. Differentiation of the bone-tissue remodeling response to axial and torsional loading in the turkey ulna. The Journal of bone and joint surgery. American volume. 1996; 78:1523-33. [PubMed: 8876580]

Rubin C, Turner AS, Bain S, Mallinckrodt C, McLeod K. Anabolism. Low mechanical signals strengthen long bones. Nature. 2001; 412:603-4. [PubMed: 11493908]

Rubin CT, Gross TS, McLeod KJ, Bain SD. Morphologic stages in lamellar bone formation stimulated by a potent mechanical stimulus. Journal of bone and mineral research : the official journal of the American Society for Bone and Mineral Research. 1995; 10:488-95. [PubMed: 7785471]

Rubin CT, Lanyon LE. Dynamic strain similarity in vertebrates; an alternative to allometric limb bone scaling. Journal of theoretical biology. 1984a; 107:321-7. [PubMed: 6717041]

Rubin CT, Lanyon LE. Regulation of bone formation by applied dynamic loads. The Journal of bone and joint surgery. American volume. 1984b; 66:397-402. [PubMed: 6699056]

Rubin CT, Lanyon LE. Regulation of bone mass by mechanical strain magnitude. Calcified tissue international. 1985; 37:411-7. [PubMed: 3930039]

Rubin CT, McLeod KJ. Promotion of bony ingrowth by frequency-specific, low-amplitude mechanical strain. Clinical orthopaedics and related research. 1994:165-74. [PubMed: 8118971] 
Rubin J, Biskobing D, Fan X, Rubin C, McLeod K, Taylor WR. Pressure regulates osteoclast formation and MCSF expression in marrow culture. Journal of cellular physiology. 1997; 170:81-7. [PubMed: 9012787]

Rubin J, Murphy T, Nanes MS, Fan X. Mechanical strain inhibits expression of osteoclast differentiation factor by murine stromal cells. American journal of physiology. Cell physiology. 2000; 278:C1126-32. [PubMed: 10837340]

Rubin J, Murphy TC, Fan X, Goldschmidt M, Taylor WR. Activation of extracellular signal-regulated kinase is involved in mechanical strain inhibition of RANKL expression in bone stromal cells. Journal of bone and mineral research : the official journal of the American Society for Bone and Mineral Research. 2002; 17:1452-60. [PubMed: 12162499]

Rubin J, Murphy TC, Rahnert J, Song H, Nanes MS, Greenfield EM, Jo H, Fan X. Mechanical inhibition of RANKL expression is regulated by H-Ras-GTPase. The Journal of biological chemistry. 2006; 281:1412-8. [PubMed: 16306046]

Rubin J, Murphy TC, Zhu L, Roy E, Nanes MS, Fan X. Mechanical strain differentially regulates endothelial nitric-oxide synthase and receptor activator of nuclear kappa B ligand expression via ERK1/2 MAPK. The Journal of biological chemistry. 2003; 278:34018-25. [PubMed: 12824189]

Rubin J, Schwartz Z, Boyan BD, Fan X, Case N, Sen B, Drab M, Smith D, Aleman M, Wong KL, Yao H, Jo H, Gross TS. Caveolin-1 knockout mice have increased bone size and stiffness. Journal of bone and mineral research : the official journal of the American Society for Bone and Mineral Research. 2007; 22:1408-18. [PubMed: 17550335]

Ryder KD, Duncan RL. Parathyroid hormone enhances fluid shear-induced [Ca2+]i signaling in osteoblastic cells through activation of mechanosensitive and voltage-sensitive $\mathrm{Ca} 2+$ channels. Journal of bone and mineral research : the official journal of the American Society for Bone and Mineral Research. 2001; 16:240-8. [PubMed: 11204424]

Salaita K, Nair PM, Petit RS, Neve RM, Das D, Gray JW, Groves JT. Restriction of receptor movement alters cellular response: physical force sensing by EphA2. Science. 2010; 327:1380-5. [PubMed: 20223987]

Salter DM, Robb JE, Wright MO. Electrophysiological responses of human bone cells to mechanical stimulation: evidence for specific integrin function in mechanotransduction. Journal of bone and mineral research : the official journal of the American Society for Bone and Mineral Research. 1997; 12:1133-41. [PubMed: 9200014]

Saunders MM, You J, Zhou Z, Li Z, Yellowley CE, Kunze EL, Jacobs CR, Donahue HJ. Fluid flowinduced prostaglandin E2 response of osteoblastic ROS 17/2.8 cells is gap junction-mediated and independent of cytosolic calcium. Bone. 2003; 32:350-6. [PubMed: 12689677]

Sawada Y, Tamada M, Dubin-Thaler BJ, Cherniavskaya O, Sakai R, Tanaka S, Sheetz MP. Force sensing by mechanical extension of the Src family kinase substrate p130Cas. Cell. 2006; 127:1015-26. [PubMed: 17129785]

Sawakami K, Robling AG, Ai M, Pitner ND, Liu D, Warden SJ, Li J, Maye P, Rowe DW, Duncan RL, Warman ML, Turner CH. The Wnt co-receptor LRP5 is essential for skeletal mechanotransduction but not for the anabolic bone response to parathyroid hormone treatment. The Journal of biological chemistry. 2006; 281:23698-711. [PubMed: 16790443]

Schaller MD. The focal adhesion kinase. The Journal of endocrinology. 1996; 150:1-7. [PubMed: 8708550]

Schlaepfer DD, Hauck CR, Sieg DJ. Signaling through focal adhesion kinase. Progress in biophysics and molecular biology. 1999; 71:435-78. [PubMed: 10354709]

Schwartz MA. Integrins and extracellular matrix in mechanotransduction. Cold Spring Harbor perspectives in biology. 2010; 2:a005066. [PubMed: 21084386]

Sen B, Guilluy C, Xie Z, Case N, Styner M, Thomas J, Oguz I, Rubin C, Burridge K, Rubin J. Mechanically induced focal adhesion assembly amplifies anti-adipogenic pathways in mesenchymal stem cells. Stem cells. 2011a; 29:1829-36. [PubMed: 21898699]

Sen B, Styner M, Xie Z, Case N, Rubin CT, Rubin J. Mechanical loading regulates NFATc1 and betacatenin signaling through a GSK3beta control node. The Journal of biological chemistry. 2009; 284:34607-17. [PubMed: 19840939] 
Sen B, Xie Z, Case N, Ma M, Rubin C, Rubin J. Mechanical strain inhibits adipogenesis in mesenchymal stem cells by stimulating a durable beta-catenin signal. Endocrinology. 2008; 149:6065-75. [PubMed: 18687779]

Sen B, Xie Z, Case N, Styner M, Rubin CT, Rubin J. Mechanical signal influence on mesenchymal stem cell fate is enhanced by incorporation of refractory periods into the loading regimen. Journal of biomechanics. 2011b; 44:593-9. [PubMed: 21130997]

Shao Y, Alicknavitch M, Farach-Carson MC. Expression of voltage sensitive calcium channel (VSCC) L-type Cav1.2 (alpha1C) and T-type Cav3.2 (alpha1H) subunits during mouse bone development. Developmental dynamics : an official publication of the American Association of Anatomists. 2005; 234:54-62. [PubMed: 16059921]

Shao Y, Czymmek KJ, Jones PA, Fomin VP, Akanbi K, Duncan RL, Farach-Carson MC. Dynamic interactions between L-type voltage-sensitive calcium channel Cav1.2 subunits and ahnak in osteoblastic cells. American journal of physiology. Cell physiology. 2009; 296:C1067-78. [PubMed: 19261907]

Shyy JY, Chien S. Role of integrins in endothelial mechanosensing of shear stress. Circulation research. 2002; 91:769-75. [PubMed: 12411390]

Smith ML, Gourdon D, Little WC, Kubow KE, Eguiluz RA, Luna-Morris S, Vogel V. Force-induced unfolding of fibronectin in the extracellular matrix of living cells. PLoS biology. 2007; 5:e268. [PubMed: 17914904]

Song EK, Rah SY, Lee YR, Yoo CH, Kim YR, Yeom JH, Park KH, Kim JS, Kim UH, Han MK. Connexin-43 hemichannels mediate cyclic ADP-ribose generation and its calcium mobilizing activity by NAD+/cyclic ADP-ribose transport. The Journal of biological chemistry. 2011

Srinivasan S, Ausk BJ, Poliachik SL, Warner SE, Richardson TS, Gross TS. Rest-inserted loading rapidly amplifies the response of bone to small increases in strain and load cycles. Journal of applied physiology. 2007; 102:1945-52. [PubMed: 17255366]

Srinivasan S, Weimer DA, Agans SC, Bain SD, Gross TS. Low-magnitude mechanical loading becomes osteogenic when rest is inserted between each load cycle. Journal of bone and mineral research : the official journal of the American Society for Bone and Mineral Research. 2002; 17:1613-20. [PubMed: 12211431]

Subauste MC, Pertz O, Adamson ED, Turner CE, Junger S, Hahn KM. Vinculin modulation of paxillin-FAK interactions regulates ERK to control survival and motility. The Journal of cell biology. 2004; 165:371-81. [PubMed: 15138291]

Sukharev S, Corey DP. Mechanosensitive channels: multiplicity of families and gating paradigms. Science's STKE : signal transduction knowledge environment. 2004; 2004:re4. [PubMed: 14872099]

Sunters A, Armstrong VJ, Zaman G, Kypta RM, Kawano Y, Lanyon LE, Price JS. Mechanotransduction in osteoblastic cells involves strain-regulated estrogen receptor alpha-mediated control of insulin-like growth factor (IGF) I receptor sensitivity to Ambient IGF, leading to phosphatidylinositol 3-kinase/AKT-dependent Wnt/LRP5 receptor-independent activation of beta-catenin signaling. The Journal of biological chemistry. 2010; 285:8743-58. [PubMed: 20042609]

Tadokoro S, Shattil SJ, Eto K, Tai V, Liddington RC, de Pereda JM, Ginsberg MH, Calderwood DA. Talin binding to integrin beta tails: a final common step in integrin activation. Science. 2003; 302:103-6. [PubMed: 14526080]

Tatsumi S, Ishii K, Amizuka N, Li M, Kobayashi T, Kohno K, Ito M, Takeshita S, Ikeda K. Targeted ablation of osteocytes induces osteoporosis with defective mechanotransduction. Cell metabolism. 2007; 5:464-75. [PubMed: 17550781]

Thompson WR, Majid AS, Czymmek KJ, Ruff AL, Garcia J, Duncan RL, Farach-Carson MC. Association of the alpha(2)delta(1) subunit with $\mathrm{Ca}(\mathrm{v}) 3.2$ enhances membrane expression and regulates mechanically induced ATP release in MLO-Y4 osteocytes. Journal of bone and mineral research : the official journal of the American Society for Bone and Mineral Research. 2011a; 26:2125-39. [PubMed: 21638318]

Thompson WR, Modla S, Grindel BJ, Czymmek KJ, Kirn-Safran CB, Wang L, Duncan RL, FarachCarson MC. Perlecan/Hspg2 deficiency alters the pericellular space of the lacunocanalicular system surrounding osteocytic processes in cortical bone. Journal of bone and mineral research : 
the official journal of the American Society for Bone and Mineral Research. 2011b; 26:618-29. [PubMed: 20814969]

Thorsen K, Kristoffersson AO, Lerner UH, Lorentzon RP. In situ microdialysis in bone tissue. Stimulation of prostaglandin E2 release by weight-bearing mechanical loading. The Journal of clinical investigation. 1996; 98:2446-9. [PubMed: 8958205]

Turner CH, Robling AG, Duncan RL, Burr DB. Do bone cells behave like a neuronal network? Calcified tissue international. 2002; 70:435-42. [PubMed: 12149636]

Vega JA, Garcia-Suarez O, Montano JA, Pardo B, Cobo JM. The Meissner and Pacinian sensory corpuscles revisited new data from the last decade. Microscopy research and technique. 2009; 72:299-309. [PubMed: 19012318]

Wagner EB, Granzella NP, Saito H, Newman DJ, Young LR, Bouxsein ML. Partial weight suspension: a novel murine model for investigating adaptation to reduced musculoskeletal loading. Journal of applied physiology. 2010; 109:350-7. [PubMed: 20522735]

Walker LM, Publicover SJ, Preston MR, Said Ahmed MA, El Haj AJ. Calcium-channel activation and matrix protein upregulation in bone cells in response to mechanical strain. Journal of cellular biochemistry. 2000; 79:648-61. [PubMed: 10996855]

Wang B, Du T, Wang Y, Yang C, Zhang S, Cao X. Focal adhesion kinase signaling pathway is involved in mechanotransduction in MG-63 cells. Biochemical and biophysical research communications. 2011; 410:671-6. [PubMed: 21693107]

Wang Y, McNamara LM, Schaffler MB, Weinbaum S. Strain amplification and integrin based signaling in osteocytes. Journal of musculoskeletal \& neuronal interactions. 2008; 8:332-4. [PubMed: 19147963]

Watabe H, Furuhama T, Tani-Ishii N, Mikuni-Takagaki Y. Mechanotransduction activates alpha(5)beta(1) integrin and PI3K/Akt signaling pathways in mandibular osteoblasts. Experimental cell research. 2011; 317:2642-9. [PubMed: 21824471]

Weinbaum S, Cowin SC, Zeng Y. A model for the excitation of osteocytes by mechanical loadinginduced bone fluid shear stresses. Journal of biomechanics. 1994; 27:339-60. [PubMed: 8051194]

Weinbaum S, Duan Y, Satlin LM, Wang T, Weinstein AM. Mechanotransduction in the renal tubule. American journal of physiology. Renal physiology. 2010; 299:F1220-36. [PubMed: 20810611]

Weinreb M, Rutledge SJ, Rodan GA. Systemic administration of an anabolic dose of prostaglandin E2 induces early-response genes in rat bones. Bone. 1997; 20:347-53. [PubMed: 9108355]

Weyts FA, Li YS, van Leeuwen J, Weinans H, Chien S. ERK activation and alpha v beta 3 integrin signaling through Shc recruitment in response to mechanical stimulation in human osteoblasts. Journal of cellular biochemistry. 2002; 87:85-92. [PubMed: 12210725]

Williams JL, Iannotti JP, Ham A, Bleuit J, Chen JH. Effects of fluid shear stress on bone cells. Biorheology. 1994; 31:163-70. [PubMed: 8729478]

Wolff J. Das Gesetz der Transformation der Knochen. Kirschwald. 1892

Xia X, Batra N, Shi Q, Bonewald LF, Sprague E, Jiang JX. Prostaglandin promotion of osteocyte gap junction function through transcriptional regulation of connexin 43 by glycogen synthase kinase 3/beta-catenin signaling. Molecular and cellular biology. 2010; 30:206-19. [PubMed: 19841066]

Xie L, Jacobson JM, Choi ES, Busa B, Donahue LR, Miller LM, Rubin CT, Judex S. Low-level mechanical vibrations can influence bone resorption and bone formation in the growing skeleton. Bone. 2006; 39:1059-66. [PubMed: 16824816]

Xiong J, Onal M, Jilka RL, Weinstein RS, Manolagas SC, O'Brien CA. Matrix-embedded cells control osteoclast formation. Nature medicine. 2011; 17:1235-41.

Yan C, Takahashi M, Okuda M, Lee JD, Berk BC. Fluid shear stress stimulates big mitogen-activated protein kinase 1 (BMK1) activity in endothelial cells. Dependence on tyrosine kinases and intracellular calcium. The Journal of biological chemistry. 1999; 274:143-50. [PubMed: 9867822]

Yasuda H, Shima N, Nakagawa N, Yamaguchi K, Kinosaki M, Mochizuki S, Tomoyasu A, Yano K, Goto M, Murakami A, Tsuda E, Morinaga T, Higashio K, Udagawa N, Takahashi N, Suda T. Osteoclast differentiation factor is a ligand for osteoprotegerin/osteoclastogenesis-inhibitory 
factor and is identical to TRANCE/RANKL. Proceedings of the National Academy of Sciences of the United States of America. 1998; 95:3597-602. [PubMed: 9520411]

Yeh CR, Chiu JJ, Lee CI, Lee PL, Shih YT, Sun JS, Chien S, Cheng CK. Estrogen augments shear stress-induced signaling and gene expression in osteoblast-like cells via estrogen receptormediated expression of beta1-integrin. Journal of bone and mineral research : the official journal of the American Society for Bone and Mineral Research. 2010; 25:627-39. [PubMed: 19821775]

You J, Reilly GC, Zhen X, Yellowley CE, Chen Q, Donahue HJ, Jacobs CR. Osteopontin gene regulation by oscillatory fluid flow via intracellular calcium mobilization and activation of mitogen-activated protein kinase in MC3T3-E1 osteoblasts. The Journal of biological chemistry. 2001a; 276:13365-71. [PubMed: 11278573]

You J, Yellowley CE, Donahue HJ, Zhang Y, Chen Q, Jacobs CR. Substrate deformation levels associated with routine physical activity are less stimulatory to bone cells relative to loadinginduced oscillatory fluid flow. J Biomech Eng. 2000; 122:387-93. [PubMed: 11036562]

You L, Cowin SC, Schaffler MB, Weinbaum S. A model for strain amplification in the actin cytoskeleton of osteocytes due to fluid drag on pericellular matrix. Journal of biomechanics. 2001b; 34:1375-86. [PubMed: 11672712]

You LD, Weinbaum S, Cowin SC, Schaffler MB. Ultrastructure of the osteocyte process and its pericellular matrix. The anatomical record. Part A, Discoveries in molecular, cellular, and evolutionary biology. 2004; 278:505-13.

Young SR, Gerard-O'Riley R, Kim JB, Pavalko FM. Focal adhesion kinase is important for fluid shear stress-induced mechanotransduction in osteoblasts. Journal of bone and mineral research : the official journal of the American Society for Bone and Mineral Research. 2009; 24:411-24. [PubMed: 19016591]

Zaman G, Saxon LK, Sunters A, Hilton H, Underhill P, Williams D, Price JS, Lanyon LE. Loadingrelated regulation of gene expression in bone in the contexts of estrogen deficiency, lack of estrogen receptor alpha and disuse. Bone. 2010; 46:628-42. [PubMed: 19857613]

Zhang YL, Frangos JA, Chachisvilis M. Mechanical stimulus alters conformation of type 1 parathyroid hormone receptor in bone cells. American journal of physiology. Cell physiology. 2009; 296:C1391-9. [PubMed: 19369447]

Zimmerman D, Jin F, Leboy P, Hardy S, Damsky C. Impaired bone formation in transgenic mice resulting from altered integrin function in osteoblasts. Developmental biology. 2000; 220:2-15. [PubMed: 10720426] 


\section{Research Highlights}

- A thorough review of mechanical signaling pathways related to bone biology.

- Covers signaling events regulating functions in cells influencing bone formation.

- Details the various mechanical loading parameters influencing signaling pathways. 

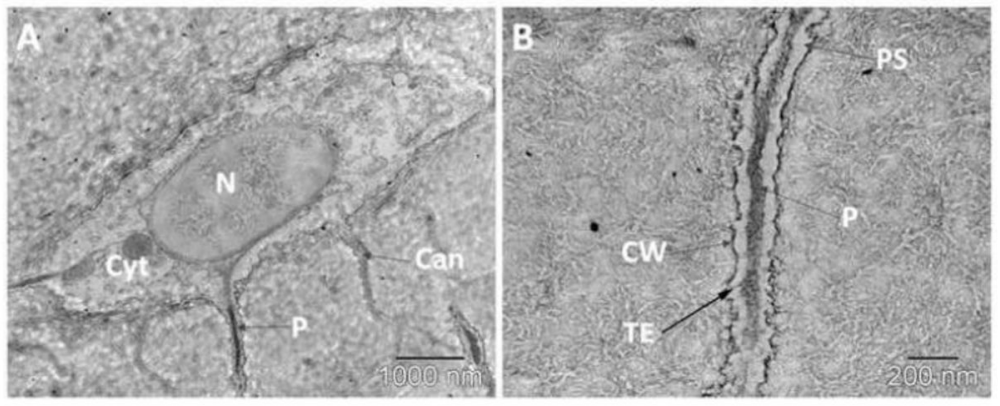

Fig. 1.

Osteocytes project long, dendrite-like processes into the mineralized bone matrix. (A) Transmission electron microscopy image of a single osteocyte containing multiple canaliculi (Can) projecting out into the mineralized bone and a prominent nucleus $(\mathrm{N})$ surrounded by cytoplasm (Cyt). The osteocyte cell process $(\mathrm{P})$ is centrally located within the canaliculus. The canaliculi make up the essential components of the network connecting osteocytes in a network. (B) A zoomed in image of a single osteocyte canaliculus with the transverse tethering elements (TE) spanning the pericellular space (PS), attaching the process (P) to the canalicular wall $(\mathrm{CW})$. 

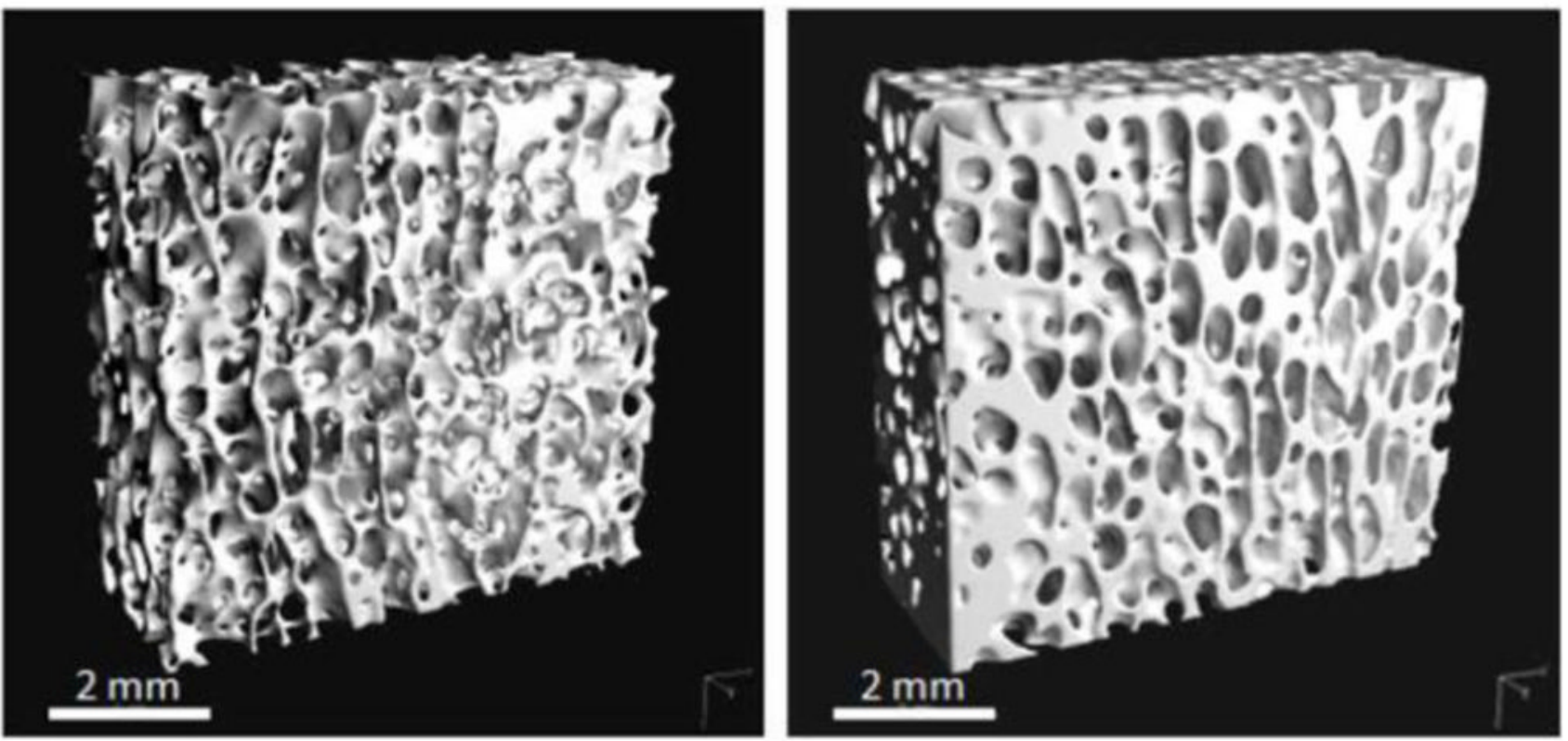

Fig. 2.

Whole bone response to mechanical challenge. Micro-computed tomography of the distal femur of adult (8y) sheep, comparing a control animal (left) to an animal subject to 20 minutes per day of $30 \mathrm{~Hz}$ of a low-level $(0.3 \mathrm{~g})$ mechanical vibration for one year (right). (from Rubin, Turner, Muller JBMR 2002a) 

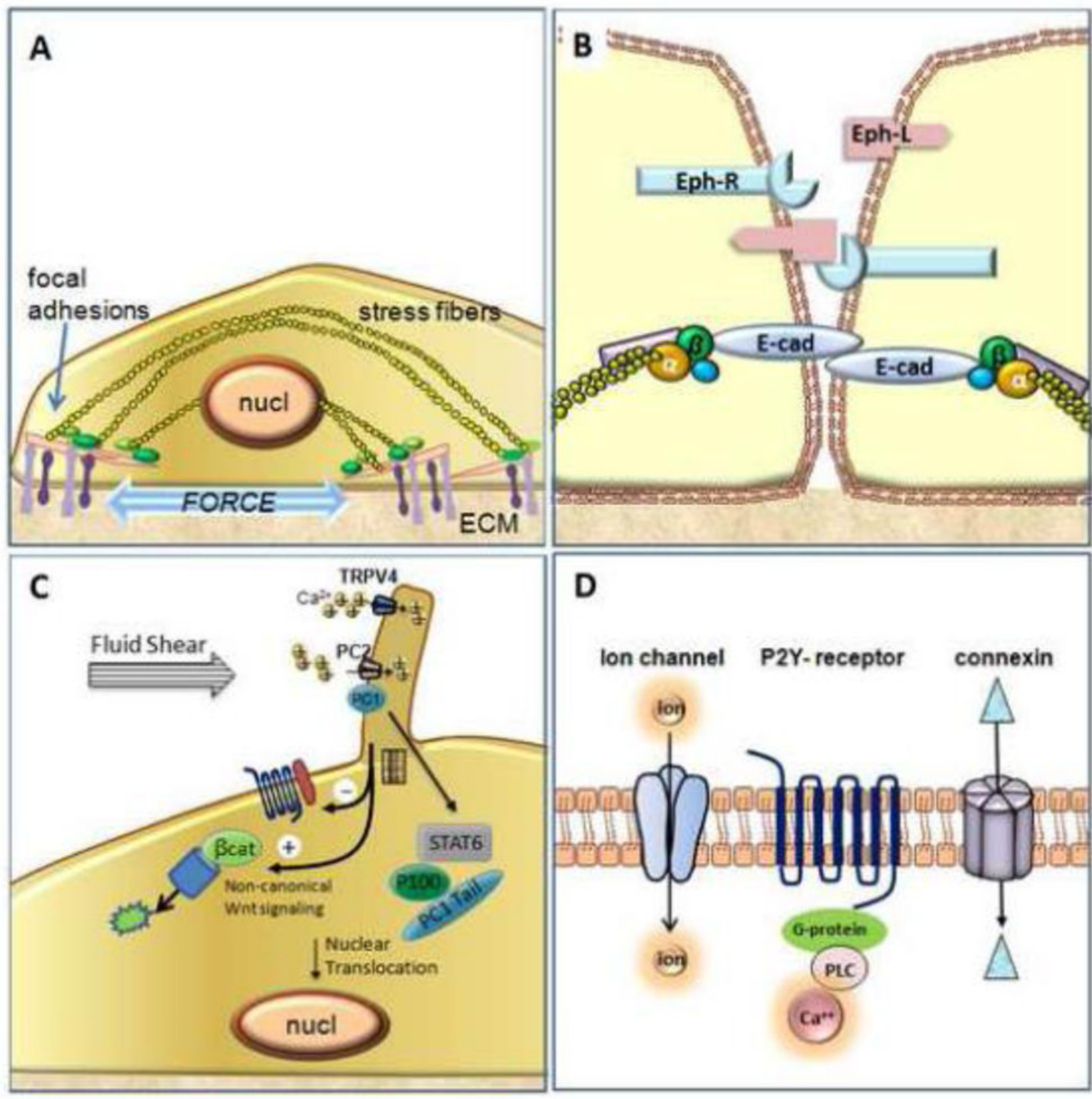

D

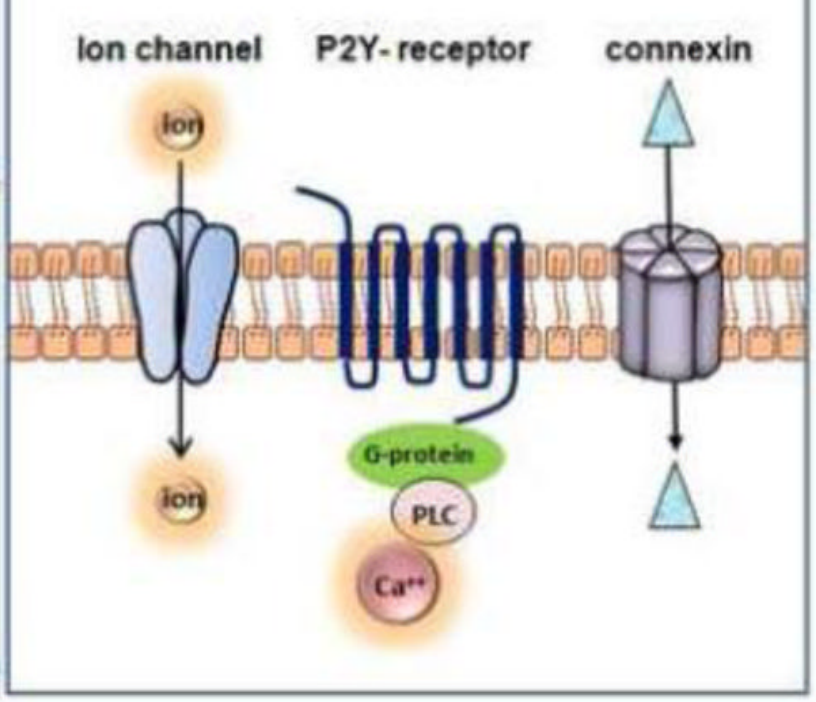

Fig. 3.

Candidate mechanotransducer systems. A: Cell cytoskeleton senses loading at the membrane through integrins that transmit force through focal adhesions and F-actin stress fibers. B: Cadherins, which connect to the cytoskeleton, are examples of outside-in signaling modifiers. Ephrins exemplify an inter-cellular signaling system regulated by movement of components within the plasma membrane. C: Primary cilia may sense flow, pressure and strain, activating ion flux through PC1 and TRPV4, which can activate Stat signals. Cilia also modulate Wnt signaling via noncanonical antagonism that leads to $\beta$-cat degradation. D: Membrane spanning proteins such as ion channels, purinergic receptors and connexins can be regulated through shear and strain. 

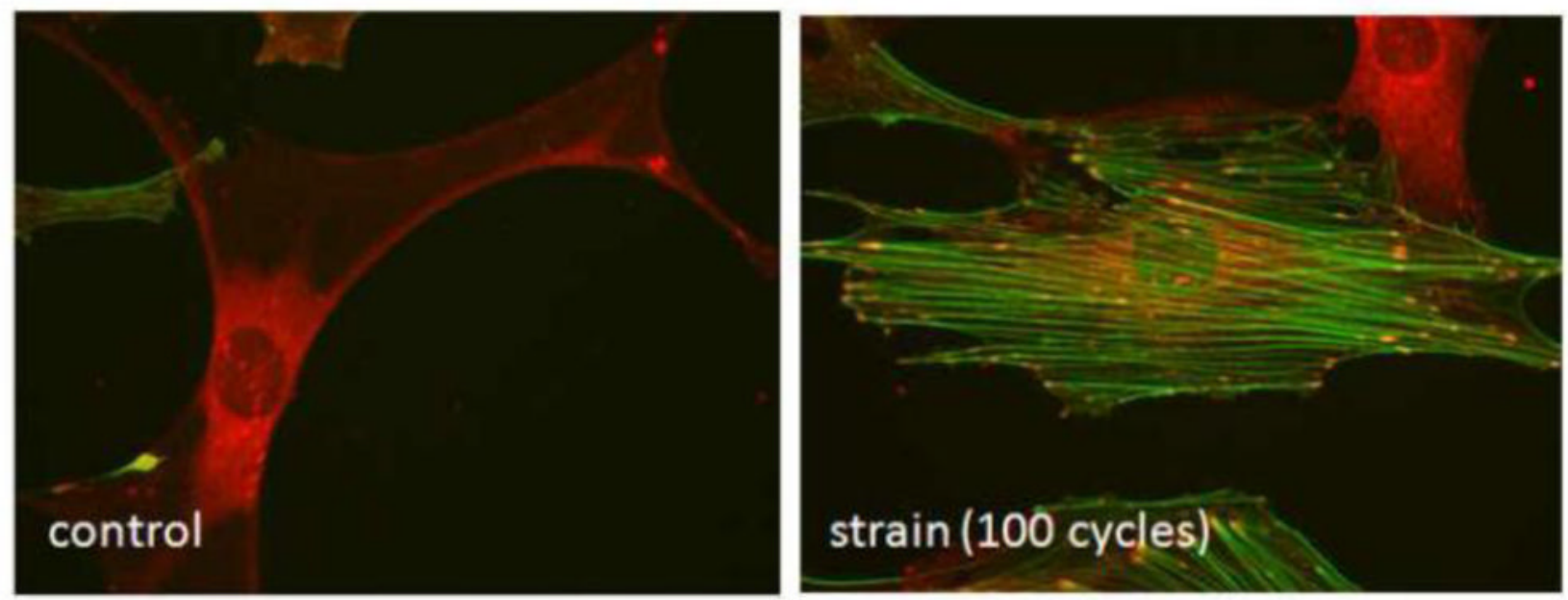

Fig. 4.

Strain induced cytoskeletal change. Bone marrow mesenchymal stem cells are stained for vinculin (red) and F-actin (green) after equibiaxial strain. In the control panel the central cell has negligible F-actin staining, and vinculin is not assembled into focal adhesions. In the strained condition, the central cell shows F-actin stress fibers that bridge between mature focal adhesions. The vinculin containing focal adhesions show convergence of signal with the F-actin signal. Micrographs are 400X. (from the laboratory of B. Sen/J. Rubin) 


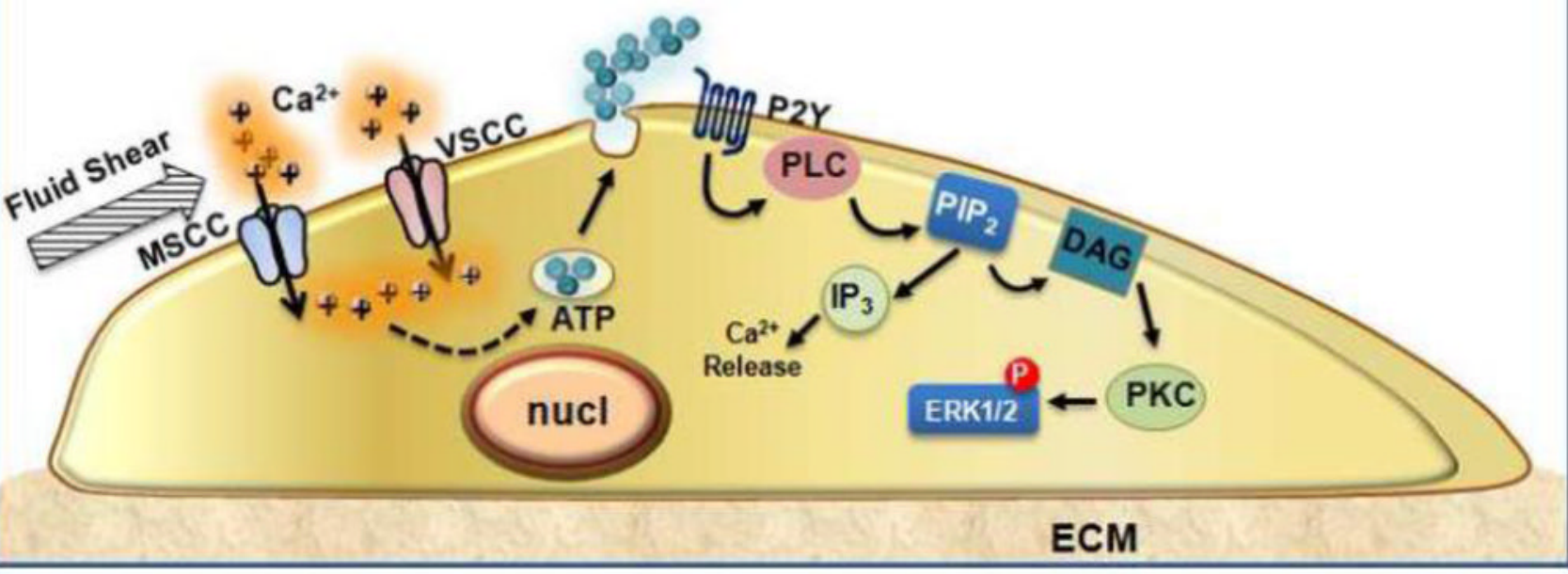

Fig. 5.

Calcium channels and purinergic signaling cooperate to regulate mechanosensitive functions in bone cells. Fluid shear stress activates a mechanosensitive channel in the plasma membrane, leading to local membrane depolarization sufficient to induce $\mathrm{Ca}^{2+}$ influx through the VSCC complex. Acting as a second messenger, $\mathrm{Ca}^{2+}$ facilitates vesicular fusion and release of ATP. Acting in an autocrine/paracrine fashion, ATP stimulates purinergic receptors that activate PLC and ERK1/2 pathways in response to mechanical signals. 


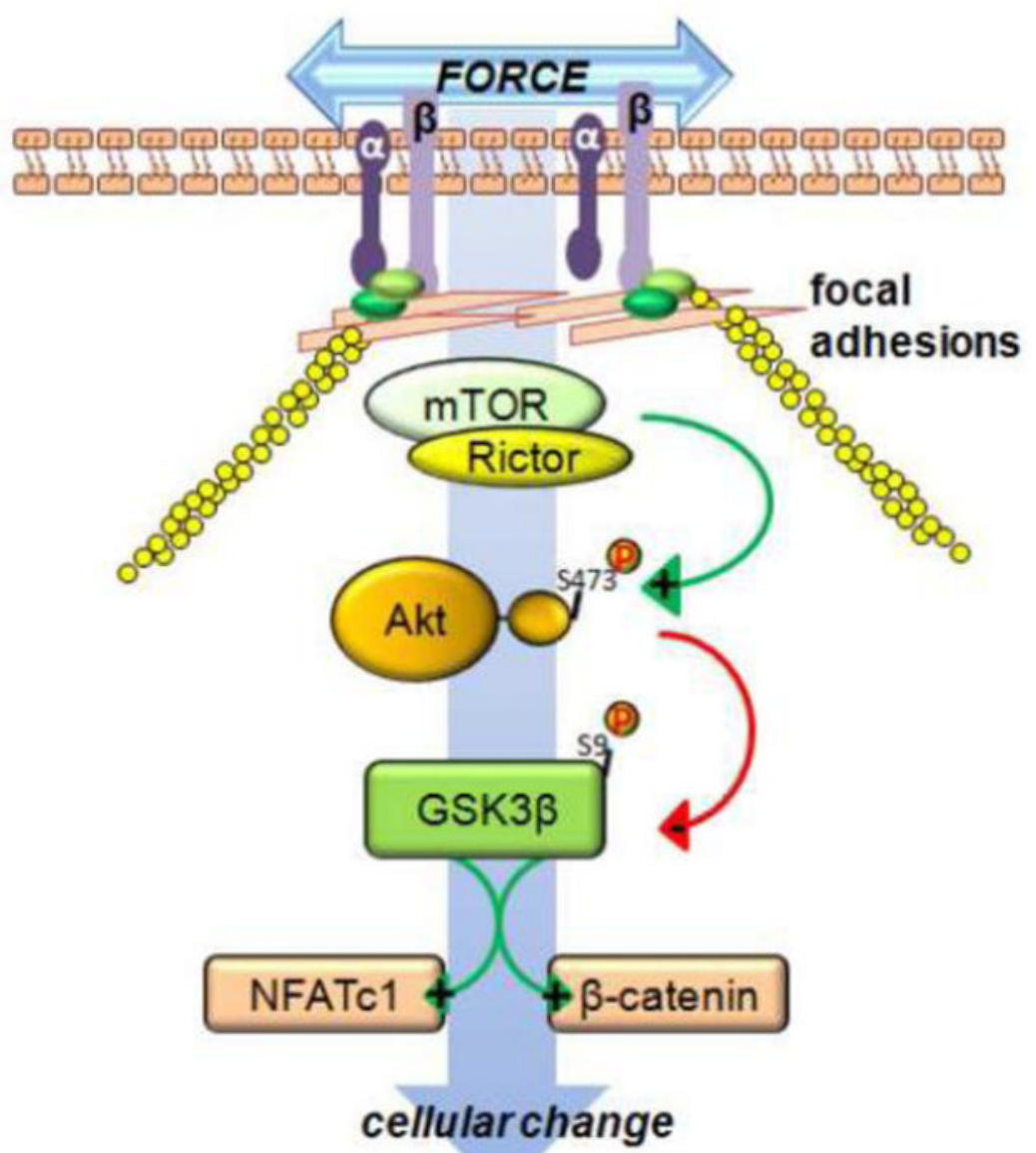

Fig. 6.

Force induced activation of $\beta$-catenin. Application of mechanical force to cells induces focal adhesion dependent activation of mTORC2. mTORC2 then activates Akt, which inactivates GSK3 $\beta$ via phosphorylation. Inhibition of GSK3 $\beta$ leads to multiple downstream events, including preservation and nuclear translocation of $\beta$-catenin, as well as prolonging the nuclear residence of NFATc1. 


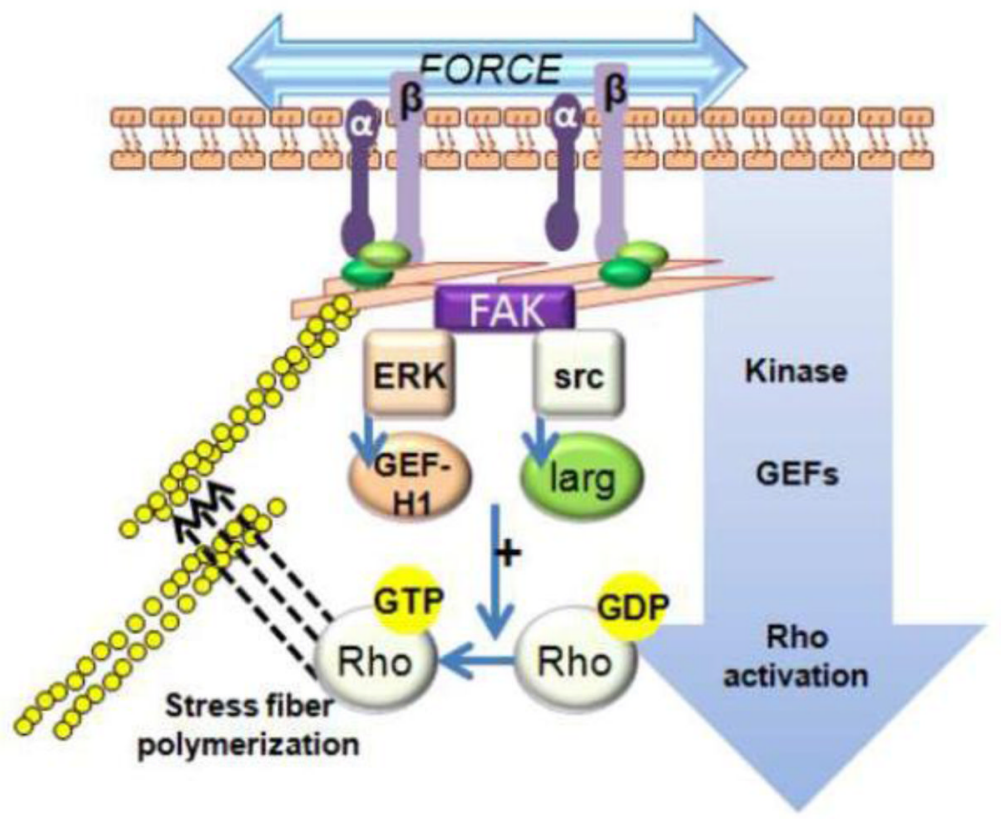

Fig. 7.

Mechanical activation of Rho via focal adhesions. Forces transmitted through focal adhesions are known to activate signaling cascades, possibly though force-induced conformational change. Involved signaling pathways include focal adhesion kinase (FAK), ERK1/2 and Src. ERK and Src can initiate Rho signaling via activation of GEFs (here shown as GEF-H1 and Larg). GDP bound RhoA is critical for assembly of new focal adhesions and stress fiber polymerization. 